\section{Seasonal Variation in Leaf Nutrient Concentration of Northern Highbush Blueberry Cultivars Grown in Conventional and Organic Production Systems}

\author{
Bernadine C. Strik ${ }^{1,3}$ and Amanda J. Vance ${ }^{2}$ \\ Department of Horticulture, Oregon State University, 4017 Agricultural and \\ Life Sciences Building, Corvallis, OR 97331
}

Additional index words. nutrient content, fruit nutrient content, leaf sampling, nutrient management, fertilization, carbon stock, Vaccinium corymbosum

\begin{abstract}
Northern highbush blueberry (Vaccinium corymbosum L.) cultivars were evaluated for leaf and fruit nutrient concentration at two production sites in 2013-14. The treatments included cultivar (Duke, Bluecrop, Draper, Legacy, Liberty, and Aurora), site ["conventional" (conventionally managed, grower-collaborator site) and "organic" (certified organic research site)], and amendment-mulch [at the organic site only; "organic mulch" (included preplant amendment and a surface mulch of yard debris compost and sawdust); and "weed mat" (no preplant amendments but with a sawdust mulch topped with weed mat)]. Leaf samples were collected every 2 weeks in all treatment plots from late April through early October of each year. Ripe fruit were subsampled from the second harvest for each cultivar. Fruiting season varied from 22 June to 19 Sept. and the highest yielding cultivar, Legacy, had $114 \%$ to $330 \%$ greater yield than the lowest, Duke, depending on year and site. Cultivar had a significant effect on all fruit nutrients except for phosphorus $(P)$ at the conventional site. Nitrogen $(N)$ and potassium (K) accounted for the largest proportion of nutrient content in the fruit, with 10 to $52 \mathrm{~kg} \cdot \mathrm{ha}^{-1}$ and 7 to $34 \mathrm{~kg} \cdot \mathrm{ha}^{-1}$ removed in the harvested fruit, respectively, depending on cultivar and site. Fruit carbon concentration ranged from $32 \%$ to $44 \%$ dry weight with 0.5 to $3.2 \mathrm{t} \cdot \mathrm{ha}^{-1}$ removed in harvested fruit. There were significant year, site, and cultivar effects on leaf nutrient concentrations on many sample dates throughout the season. Despite relatively large differences in management between sites and yield and fruiting season among cultivars, the pattern in leaf nutrient concentration over sampling time was relatively similar between sites and years. Leaf manganese (Mn) and aluminum (Al) concentrations were higher when plants were grown with weed mat as compared with the organic mulch treatment, because soil pH was lower under weed mat than in the organic mulch treatment. 'Liberty' had the highest leaf $\mathbf{N}$ throughout much of the season at the conventional site. There were relatively large differences among cultivars in leaf magnesium (Mg), calcium (Ca), and $\mathrm{K}$ when sampling from mid-July to autumn at both sites. 'Duke' and 'Bluecrop' tended to have the highest leaf $K$ during this period, whereas 'Legacy' and 'Liberty' had the lowest. There were greater differences in leaf $\mathrm{Ca}$ among cultivars at the conventional site than at the organic site. 'Draper' and 'Legacy' had higher leaf $C a$ than 'Duke'. Leaf nutrient concentrations were within the current published sufficiency levels on many sample dates throughout the season for $\mathrm{P}, \mathbf{M g}$, sulfur (S), Mn, and zinc ( $\mathrm{Zn}$ ), on many dates in midseason for $\mathrm{K}$ and $\mathrm{Ca}$, and from mid- to lateseason for boron (B) and iron (Fe). However, only when sampled in late July to early August, the current recommended sampling time, was leaf $\mathrm{N}$ within sufficiency range. Moreover, there was an effect of cultivar on the concentration of most leaf nutrients at both sites when sampled in late July to early August. The recommended sampling time to determine plant nutrient status in northern highbush blueberry should remain at late July to mid-August, regardless of cultivar, when most nutrients are relatively stable. We recommend lowering the leaf sufficiency range for $\mathrm{P}$ and copper $(\mathrm{Cu})$ based on our findings.
\end{abstract}

Commercial blueberry (Vaccinium sp.) growers are encouraged to develop fertilization programs based on recommended starting rates of $\mathrm{N}$ fertilizer, which depend on blueberry type and planting age, with adjustments of $\mathrm{N}$ and other macro- and micronutrients based on periodic analyses of soil for $\mathrm{pH}$ and nutrients and leaf tissue annually (Hart et al., 1992, 2006; Krewer et al., 2007).

Leaf sampling for determination of blueberry plant nutrient status is recommended for the most recent fully expanded leaves similar among these currently available nutrient management guides.

Leaf nutrient levels have been shown to vary over the growing season in many berry crops including floricane-fruiting blackberry (Rubus sp.) (Clark et al., 1988; Mohadjer et al., 2001), primocane-fruiting blackberry (Strik, 2015), floricane-fruiting raspberry (Rubus idaeus L.) (Hughes et al., 1979; John et al., 1976; Kowalenko, 1994; Wright and Waister, 1980), and in blueberry (Bailey et al., 1962; Ballinger, 1966; Chuntanaparb and Cummings, 1980; Clark et al., 1989; Spiers, 1982). Leaf samples for tissue analysis should be collected at a time when most or all nutrients are relatively stable to allow for comparison purposes among years and development of relevant nutrient sufficiency levels.

Cultivars of blackberry (Fernandez et al., 2015; Harkins et al., 2014; Strik, 2015), raspberry (John et al., 1976) and blueberry (Eaton and Meehan, 1971) have been shown to differ in leaf nutrient levels when sampled in midseason. In contrast, Clark et al. (1988) found no difference among blackberry cultivars that had a similar parentage. When leaf nutrient levels were evaluated over the season, Amling (1958) recommended sampling northern highbush blueberry in Michigan for tissue analysis during a 4-week period before and including the first portion of fruit harvest. Bailey et al. (1962) recommended tissue sampling be done before fruit ripening in 'Rubel' in Massachusetts. In North Carolina, when studying 'Wolcott', Ballinger (1966) recommended leaf sampling be done during a 2- to 3-week period beginning at the time of last fruit harvest. Clark et al. (1989) recommended 'Bluecrop' be sampled in mid-July to mid-August after fruit harvest in Arkansas and found that 'Bluechip' and 'Croatan' differed in some nutrients but not others (Clark et al., 1994). Sampling blueberry cultivars separately for tissue analysis is recommended; however, there is presently no recommended change in sampling time for cultivars that have different fruiting seasons in the northwestern and northeastern United States (Hart et al., 1992, 2006).

The objectives of this study were to evaluate the impact of sample date over two seasons and production systems (conventional and organic) on leaf nutrient levels in six commonly grown cultivars of northern highbush blueberry differing in fruiting season and productivity. In addition, we evaluated the impact of cultivar on nutrient allocation to fruit, as it is hypothesized that high yield and or fruiting season may affect leaf nutrient concentration.

\section{Materials and Methods} eastern (Hart et al., 1992) United States or 2 weeks after harvest in the southeastern United States where fruit harvest occurs relatively early in the season (Krewer et al., 2007). Leaf nutrient status, as compared with published sufficiency levels (Hart et al., 1992, 2006; Krewer et al., 2007), coupled with observations of plant growth are used to develop nutrient management programs. The recommended nutrient sufficiency levels are
Study sites. The study was conducted at two mature northern highbush blueberry sites, "conventional" and "organic." The conventional site was a large commercial blueberry farm located near Salem, OR (lat. $45^{\circ} 00^{\prime} \mathrm{N}$, long. $122^{\circ} 56^{\prime} \mathrm{W}$ ). Soil at the site is mapped as a Woodburn silt loam (fine-silty mixed superactive mesic Aquultic Argixeroll). 
Douglas fir (Pseudotsuga menziesii M.) sawdust amendment was incorporated into the top 0.15 to $0.25 \mathrm{~m}$ of soil before forming raised beds ( $\approx 0.3 \mathrm{~m}$ high) using a bed shaper just before planting. All cultivars (see below) were planted in Oct. 2006, except for Duke (Oct. 2005) and Bluecrop (Oct. 1974). After planting, the in-row area was mulched with douglas fir sawdust at a depth of 5 to $8 \mathrm{~cm}$. No further sawdust mulch was applied from planting to the present study in 2013-14. All of the cultivars except 'Bluecrop' were irrigated using two lines of polyethylene drip tubing (Netafim, Fresno, CA) with $1.9 \mathrm{~L} \cdot \mathrm{h}^{-1}$ in-line pressure-compensating emitters spaced at $0.45-\mathrm{m}$ intervals. The tubing was located along the row near the base of the plants, one per side, under the mulch. Plants were irrigated daily in three 10-min sets from approximately June to September, unless scheduling required adjustment based on grower sampling of soil water content (using a soil probe). 'Bluecrop' was irrigated using overhead impact sprinklers with scheduling adjusted as mentioned previously.

The organic site was planted in Oct. 2006 at the North Willamette Research and Extension Center, Aurora, OR (lat. $45^{\circ} 28^{\prime} \mathrm{N}$, long. $\left.122^{\circ} 76^{\prime} \mathrm{W}\right)$. Soil at the site is mapped as a Willamette silt loam (fine-silty mixed superactive mesic Pachic Ultic Argixeroll). The site was first certified organic by a U.S. Department of Agriculture accredited agency (Oregon Tilth Certified Organic, Corvallis, OR) in May 2008. After adding any preplant amendments in late September, if used (see below), raised beds were constructed using a bed shaper; beds were $0.3 \mathrm{~m}$ high and $0.4 \mathrm{~m}$ wide at the top and $1.5 \mathrm{~m}$ wide at the base when established, but settled to a height of $\approx 0.25 \mathrm{~m}$ by Autumn 2007. Plants were irrigated using a single line of polyethylene drip tubing (Netafim, Fresno, CA) with $2 \mathrm{~L} \cdot \mathrm{h}^{-1}$ pressure-compensating, inline emitters spaced every $0.3 \mathrm{~m}$. The line was located along the row near the base of plants, under the mulch. Irrigation was controlled by electric solenoid valves and an automatic timer set weekly and scheduled to maintain a soil water content suitable for highbush blueberry production [ $25 \%$ to $30 \%$ soil water content from the soil surface to $0.3 \mathrm{~m}$, based on time domain reflectometry measurements (SoilMoisture Equipment Corp., Santa Barbara, CA)].

Amendment and mulch, organic site. Two preplant amendment and mulch treatments were evaluated at the organic site. The "organic mulch" treatment included a preplant

Received for publication 27 May 2015. Accepted for publication 7 Aug. 2015.

We appreciate the valuable assistance of Gil Buller, former Senior Faculty Research Assistant at the North Willamette Research and Extension Center, OSU; Javier Fernandez-Salvador, graduate student; and Cliff Pereira, Research Associate, Department of Statistics, OSU. We also appreciate the funding support provided by the Washington Blueberry Commission.

${ }^{1}$ Professor.

${ }^{2}$ Faculty Research Assistant.

${ }^{3}$ Corresponding author. E-mail: bernadine.strik@ oregonstate.edu. amendment and a mulch. Before planting, yard debris compost $(\approx 2 \mathrm{~cm}$ deep-centered on the row; $76 \mathrm{~m}^{3} \cdot \mathrm{ha}^{-1}$ ) and douglas fir sawdust $\left(\approx 5 \mathrm{~cm}\right.$ deep; $\left.200 \mathrm{~m}^{3} \cdot \mathrm{ha}^{-1}\right)$ were incorporated before forming the raised beds in Sept. to Oct. 2006. Immediately after planting, the beds were first mulched with yard debris compost $\left(\approx 2 \mathrm{~cm}\right.$ deep; $\left.76 \mathrm{~m}^{3} \cdot \mathrm{ha}^{-1}\right)$ and then the compost was topped with sawdust $\left(\approx 7.5 \mathrm{~cm}\right.$ deep; $\left.300 \mathrm{~m}^{3} \cdot \mathrm{ha}^{-1}\right)$. The mulches were spread mechanically in $0.75-\mathrm{m}$ wide strips under, and on each side of the plant rows. The yard debris compost used at planting (Wilt Farms, Corvallis, OR) and when the mulch needed replenishing in Jan. to Feb. 2008, 2011, and 2013 (Rexius, Eugene, OR) consisted of well-composted rye grass clippings (predominantly) and yard waste clippings, respectively. The yard debris composts had average properties of $7.5 \mathrm{pH}, 0.7 \mathrm{dS} \cdot \mathrm{m}^{-1}$ electrical conductivity, a carbon to $\mathrm{N}$ ratio of 12 (Wilt) to 21 (Rexius), $1.3 \% \mathrm{~N}, 1.7 \%$ (Rexius) to $6.9 \%$ (Wilt) $\mathrm{Ca}$, and $562 \mathrm{ppm}$ (Rexius) to $9735 \mathrm{ppm}$ (Wilt) $\mathrm{K}$ over the establishment years. The slow-release N provided by the yard debris compost was estimated at roughly $25 \mathrm{~kg} / \mathrm{ha} /$ year (3\% of total compost$\mathrm{N}$ applied), based on experience with similar composts applied before planting in grass (Sullivan et al., 2003) and sweet corn (Gale et al., 2006). The compost was topped with douglas fir sawdust (Decorative Bark, Lyons, OR) with the goal of creating a barrier to weed establishment. The soil $\mathrm{pH}$ at this site, before any soil amendments, was 4.9.

The second mulch treatment, "weed mat", involved no preplant amendments, but included a mulch of douglas fir sawdust $(\approx 7.5 \mathrm{~cm}$ deep; $300 \mathrm{~m}^{3} \cdot \mathrm{ha}^{-1}$ ) topped with black, woven polyethylene groundcover ("weed mat"; with a water flow rate of $6.8 \mathrm{~L} \cdot \mathrm{h} \cdot \mathrm{m}^{-2}$ and a density of $0.11 \mathrm{~kg} \cdot \mathrm{m}^{-2}$ as measured by the manufacturer; TenCate Protective Fabrics, OBC Northwest, Canby, OR). The weed mat was $1.5 \mathrm{~m}$ wide and was centered over the planting beds before securing it in place with landscape staples. A $20-\mathrm{cm}$ diameter hole was cut in the weed mat for each plant and covered with $5 \mathrm{~cm}$ of douglas fir sawdust mulch $\left(1.4 \mathrm{~m}^{3} \cdot \mathrm{ha}^{-1}\right)$ after planting. The weed mat was replaced in Dec. 2010 with a similar product and was installed as a "zippered" system (overlapping and secured with landscape staples) such that the weed mat could be opened to apply any needed granular fertilizers. The sawdust mulch under the weed mat did not require replenishment in 2010.

Cultivars. The cultivars studied at both sites ('Duke', 'Bluecrop', 'Draper', 'Legacy', 'Liberty', and 'Aurora') were selected to represent a range in fruiting or harvest season and important commercial cultivars grown in the Pacific northwestern United States. Standard, 18-month-old container stock $(3.8 \mathrm{~L})$, with two to four whips per plant, was purchased from a commercial nursery and transplanted into the field at an in-row spacing of $0.75 \mathrm{~m}$ and a between-row spacing of $3.0 \mathrm{~m}$ (4385 plants/ha) at both sites.

Experimental design. At the conventional grower site, cultivars were grown in large blocks of $\approx 15$ ha. There were four replicates per cultivar with each experimental unit $\approx 0.5$ ha in size. At the organic site, each experimental unit consisted of a 5-m plot containing seven plants. The experimental design was a splitplot with amendment-mulch treatment as the main effect and cultivar as the split plot with two replicates of the main effect.

Fertilization. The rate of fertilizer nutrients and the products applied at each site in 2013 and 2014 are presented in Table 1. At the conventional site for all cultivars except Bluecrop, granular fertilizers were applied to the in-row area in early to mid-April, before the irrigation season, after which plants were fertigated from May to mid-June of each year. In 'Bluecrop', granular fertilizers (custom blends) were applied in April, May, and June of each year. Boron (as borax) was applied in autumn of each year (Table 1).

At the organic site, two fertilizer products were used to achieve the total rate of $\mathrm{N}$ applied (Table 1). Half of the $\mathrm{N}$ was applied via fertigation using two liquid sources of $\mathrm{N}$ dosed in seven equal portions from mid-April through June of each year. The remaining $\mathrm{N}$ was applied using a granular soybean meal applied in early March on top of the organic mulch or under the weed mat. In addition, 258 $\mathrm{kg} \cdot \mathrm{ha}^{-1}$ of $\mathrm{Ca}$ (calcium sulfate applied as gypsum) and $5.5 \mathrm{~kg} \cdot \mathrm{ha}^{-1}$ of $\mathrm{Mg}$ and 7.3 $\mathrm{kg} \cdot \mathrm{ha}^{-1}$ of $\mathrm{S}$ (as magnesium sulfate) was applied to all plots at the organic site in late Winter 2013 (Table 1). Elemental S was applied to the surface of the organic mulch plots on May $2012\left(335 \mathrm{~kg} \cdot \mathrm{ha}^{-1}\right)$ when soil $\mathrm{pH}$ had increased to 6.7 and in Feb. 2013 (112 $\mathrm{kg} \cdot \mathrm{ha}^{-1}$ ) when $\mathrm{pH}$ was 5.8. No S was applied to the weed mat treatment as soil $\mathrm{pH}$ was within the recommended range of 4.5 to 5.5 (Hart et al., 2006).

Planting management. Other than the differences described above, management was similar among sites. A permanent grass cover crop [fine fescue, cultivar unknown, at the conventional site and certified organic grass (Festulolium braunii $\mathrm{K}$. Richt.) at the organic site] was grown between rows and mowed during the growing season as required. Plants were pruned annually in winter. Weeds were managed using preemergent herbicides at the conventional site and hand removal at the organic site. Insect and any disease pests were managed according to standard, approved practices for conventional (DeFrancesco et al., 2014; Strik et al., 1993) or organic production [Organic Materials Review Institute (OMRI), 2013].

Data collection. Tissue samples for nutrient testing were collected approximately every 2 weeks from 23 Apr. to 7 Oct. in 2013 and 21 Apr. to 6 Oct. 2014 for a total of 13 samples per year. Stage of plant development was recorded for each cultivar and year, including taking photos on each sample date. Stage of development ranged from shoots averaging $\approx 4$ - to 5 -cm long and percent bloom ranging from $15 \%$ to $65 \%$ on the first sample date in April, depending on cultivar and site, to just after fruit harvest in autumn for 'Aurora' at the grower site (Table 2) and when shoot length ranged from 0.3 to $0.6 \mathrm{~m}$ 
Table 1. Fertilizer nutrients applied at the certified organic (North Willamette Research and Extension Center, Aurora, OR) and the conventional, growercollaborator (Salem, OR) sites in 2013 and 2014.

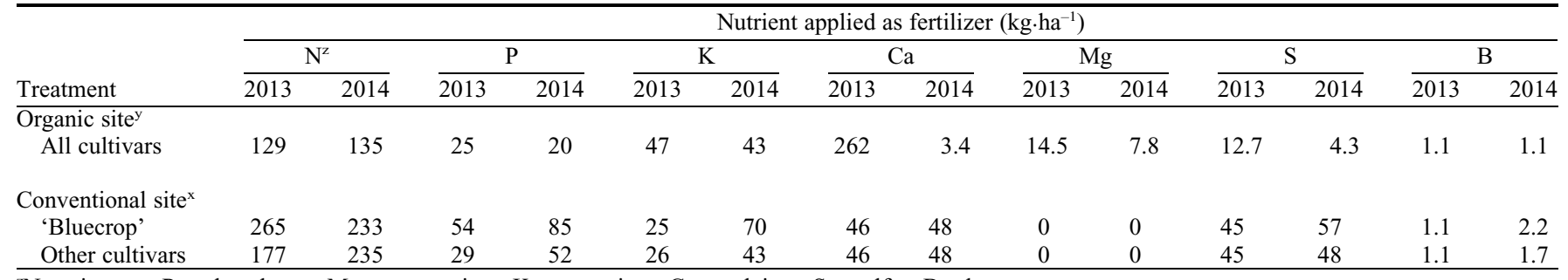

${ }^{\mathrm{z}} \mathrm{N}=$ nitrogen; $\mathrm{P}=$ phosphorus; $\mathrm{Mg}=$ magnesium; $\mathrm{K}=$ potassium; $\mathrm{Ca}=$ calcium; $\mathrm{S}=$ sulfur; $\mathrm{B}=$ boron.

${ }^{\mathrm{y}}$ Fertilizers applied at the organic site included a soluble grain fermentation and nitrate of soda blend (4N-0.9P-0.4K; Converted Organics of California,

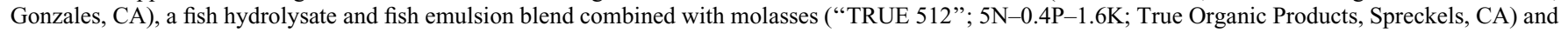
a granular soybean meal ("Phyta-Grow Leafy Green", 7N-0.4P-1.6K; California Organic Fertilizers, Fresno, CA) in each year. In 2013 , an additional 258 kg.ha ${ }^{-1}$ of Ca (calcium sulfate applied as gypsum) and $5.5 \mathrm{~kg} \cdot \mathrm{ha}^{-1}$ of $\mathrm{Mg}$ and $7.3 \mathrm{~kg} \cdot \mathrm{ha}^{-1}$ of S (as magnesium sulfate) were applied in late Winter 2013 . The elemental S, applied to the amendment-mulched plots only, is not included in the table.

${ }^{x}$ Fertilizers applied at the conventional site included three granular applications of custom fertilizer blends to 'Bluecrop' and, for the other cultivars, mainly a granular application of urea $(20-0-0)$ and then fertigation with $(4.2 \mathrm{~N}-5.5 \mathrm{P}-0.5 \mathrm{~K}$ and $20 \mathrm{~N}-0 \mathrm{P}-0 \mathrm{~K})$.

Table 2. Hand-harvested yield and fruiting season of six cultivars grown at the certified organic (North Willamette Research and Extension Center, Aurora, OR) and the conventional, grower-collaborator (Salem, OR) sites in 2013 and 2014. Yield at the organic site is averaged over amendment-mulch treatment.

\begin{tabular}{|c|c|c|c|c|}
\hline \multirow[b]{2}{*}{ Treatment } & \multicolumn{2}{|c|}{ Harvested yield $\left(\mathrm{t} \cdot \mathrm{ha}^{-1}\right)$} & \multicolumn{2}{|c|}{ Fruiting season } \\
\hline & 2013 & 2014 & 2013 & 2014 \\
\hline \multicolumn{5}{|l|}{ Organic site } \\
\hline 'Duke' & 8.9 & 14.0 & 26 June to 3 July & 23 June to 10 July \\
\hline 'Bluecrop' & 22.2 & 28.9 & 6 July to 7 Aug. & 2 July to $11 \mathrm{Aug}$. \\
\hline 'Draper' & 11.9 & 17.2 & 10 to 24 July & 10 to 29 July \\
\hline 'Legacy' & 38.3 & 40.8 & 17 July to 21 Aug. & 16 July to 11 Aug. \\
\hline 'Liberty' & 20.1 & 23.6 & 17 July to 21 Aug. & 16 July to 11 Aug. \\
\hline 'Aurora' & 23.1 & 16.0 & 31 July to 4 Sept. & 5 to 17 Aug. \\
\hline \multicolumn{5}{|c|}{ Conventional site } \\
\hline 'Duke' & 17.7 & 18.1 & 22 June to 5 July & 30 June to 15 July \\
\hline 'Bluecrop' & 33.9 & 24.3 & 3 July to 14 Aug. & 30 June to 27 Aug. \\
\hline 'Draper' & 35.9 & 30.6 & 8 July to 13 Aug. & 3 July to 22 Aug. \\
\hline 'Legacy' & 45.1 & 38.7 & 10 July to 6 Sept. & 11 July to 23 Sept. \\
\hline 'Liberty' & 28.7 & 19.6 & 18 July to 7 Sept. & 19 July to 22 Sept. \\
\hline 'Aurora' & 27.7 & 27.8 & 10 Aug. to 12 Sept. & 3 Aug. to 19 Sept. \\
\hline
\end{tabular}

for all cultivars on the last sample date in October (data not shown).

About 50 of the most recent, fully expanded leaves were sampled per experimental unit on each date per standard recommendation (Hart et al., 2006). Leaves were sampled from current season shoots growing under flower, fruit, or recent fruiting sites, depending on sample date; vigorous growing vegetative shoots or whips were avoided (Hart et al., 2006). Leaves were not washed before shipping (Hart et al., 2006) overnight to Brookside Laboratories (New Bremen, $\mathrm{OH}$ ) for analysis of nutrient content. Leaf $\mathrm{N}$ and carbon (C) were determined using a combustion analyser with an induction furnace and a thermal conductivity detector (Gavlak et al., 1994). Other nutrients, including $\mathrm{P}, \mathrm{K}, \mathrm{Ca}$, $\mathrm{Mg}, \mathrm{B}, \mathrm{Cu}, \mathrm{Mn}, \mathrm{Zn}$, and $\mathrm{Al}$, were determined using an inductively coupled plasma spectrophotometer after wet ashing the samples in nitric/perchloric acid (Gavlak et al., 1994).

All cultivars were hand harvested at approximately weekly intervals, depending on cultivar, at both sites. At the conventional, grower site the latest ripening fruit on some cultivars were left on the bush (to "hang") and were later harvested by machine for the processed market; this is not an unusual practice in this production region. Total yield data and fruiting season were recorded. On the second harvest for each cultivar, 50 berries were subsampled from each experimental unit and were overnight priority shipped with ice packs to Brookside Laboratories for analysis of moisture content and nutrients, as described above. Fruit moisture and nutrient concentration data along with total yield were used to calculate nutrients removed in harvested fruit.

Soil samples were collected at each site (a combined sample for each cultivar at the conventional site and in each mulch type at the organic site) on 14 Oct. 2014 using a 2.4-cm diameter, 0.5-m long, slotted, open-side, chrome-plated steel soil probe (Soil Sampler Model Hoffer, JBK Manufacturing, Dayton, $\mathrm{OH})$. Mulch, if present, was removed from the soil surface before sampling to a depth of $0.3 \mathrm{~m}$ at the center of the row, between plants and within the water emitter drip zone or fertilization area. Soil was sent for analysis of macro- and micronutrient content and $\mathrm{pH}$ to Brookside Laboratories.

Data analysis. Leaf nutrient data at the organic site were analyzed to first determine the effect of amendment-mulch on tissue nutrient concentration. The data were analyzed by sample date using PROC MIXED (SAS version 9.3) for a split-split plot with year as the main effect $(n=2)$, amendment-mulch as the sub-plot effect $(n=2)$, and cultivar as the sub-subplot effect $(\mathrm{n}=6)$ with a Satterthwaite approximation used, as needed, for main effect comparisons. Results indicated that there was only a significant effect of amendment-mulch on leaf $\mathrm{Mn}$ and $\mathrm{Al}$ concentration on several sample dates. Data for all other nutrients were thus pooled for the amendment-mulch treatment for subsequent analyses. There was no effect of amendmentmulch on fruit nutrient data, so these treatments were pooled for subsequent analysis.

Leaf nutrient data for all years and sites were analyzed by sample date with year as the main effect $(n=2)$, site as the sub-plot plot effect $(n=2)$, and cultivar as the subsubplot effect $(\mathrm{n}=6)$ using PROC MIXED. Considering the many significant interactions between year, cultivar, and site for many nutrients on many sample dates, the data were then also analyzed by year and site for each of the 13 sample dates with year as the main effect $(n=2)$ and cultivar as the subplot effect $(n=6)$ for each site.

The two sample dates that fell within the recommended tissue nutrient sampling time for blueberry (Hart et al., 2006), late July and early August, were analyzed by site to determine whether tissue nutrient levels were significantly affected by sample date.

Data for fruit nutrient concentration were analyzed as a split-split plot with year as the main effect $(n=2)$, site as the sub-plot effect $(\mathrm{n}=2)$ and cultivar as the sub-subplot effect $(n=6)$. There was a year $\times$ site and site $\times$ cultivar interaction for many of the fruit nutrients and thus data were also analyzed and presented by site. Mean comparison was performed using LSMEANS.

PROC UNIVARIATE and the ShapiroWilk procedure were used to assess normality of the data for all the aforementioned analyses. As the tissue nutrient concentration of many nutrients was not normal, a $\log$ transformation was used to improve homogeneity of variance and to assess proportional effects. Data were back transformed for presentation. 
There was no statistical analysis on the yield, fruiting season, and soil nutrient data as these were not replicated.

\section{Results and Discussion}

Weather. The weather was not expected to differ much between the two sites considering their relative proximity and the macroclimate of the Willamette Valley of Oregon. Weather data collected from an Agrimet weather station located $\approx 0.5 \mathrm{~km}$ from the organic site are presented in Table 3. There was relatively little difference in mean air temperature during the months in which leaf samples were collected (May through September). However, mean maximum temperature in May and July was higher in 2014 than in 2013, whereas the opposite was found for June. Precipitation was typical for this region with most rainfall occurring in the months of October through May in both years. The relatively high rainfall that was recorded in Sept. 2013 and Oct. 2014 fell just before (28-29 Sept.) or after the last leaf sample date (6 Oct.; data not shown) and thus was expected to have relatively little effect on differences in tissue nutrient concentrations among years.

Soil. A pooled soil sample was taken for each cultivar at the conventional site and for each cultivar $\times$ amendment-mulch treatment at the organic site (no replication) in Oct. 2014. At the conventional site, soil $\mathrm{pH}$ ranged from 4.0 to 5.4 with the lowest $\mathrm{pH}$ found in 'Bluecrop' (4.0) and 'Aurora' (4.5) (a soil pH of $4.5-5.5$ is recommended; Hart et al., 2006). Soil organic matter (OM) content ranged from $2.9 \%$ ('Bluecrop') to $5.9 \%$ ('Aurora'). The soil had a range of 13-38 $\mathrm{ppm}$ $\mathrm{NO}_{3}-\mathrm{N}, 2.9-5.9 \mathrm{ppm} \mathrm{NH}-\mathrm{N}, 212-391 \mathrm{ppm}$ P (Bray I) (25-40 ppm; Hart et al., 2006), 111-215 ppm K (100-250 ppm), 458-1289 ppm Ca with lowest level in 'Bluecrop' (1000 ppm; Hart et al., 2006), 72-235 ppm Mg with lowest level in 'Bluecrop' (60 ppm; Hart et al., 2006), 0.43-0.66 ppm B (0.5-1.0 ppm; Hart et al., 2006), 348-454 ppm Fe, 10-38 ppm Mn, 6.5-11.9 Cu, 2.3-8.1 ppm Zn, and 1112-1438 ppm $\mathrm{Al}$, depending on cultivar.

Incorporation of yard debris compost before planting in 2006 had an impact on soil nutrient content in Oct. 2014 with these plots having a higher $\mathrm{pH}$ (5.8-6.3 compared with 4.8-5.4 for the unamended weed mat plots), OM (5.7\% to $6.9 \%$ vs. $3.7 \%$ to $4.5 \%$ ), P (195-277 vs. $168-205$ ppm), K (341-436 vs. $179-293$ ppm), Ca (1568-1838 vs. 737$895 \mathrm{ppm}), \mathrm{Mg}$ (240-284 vs. 173-231 ppm), B (0.35-0.50 vs. $0.21-0.33$ ppm), $\mathrm{Mn}(40-47$ vs. $25-41 \mathrm{ppm}), \mathrm{Zn}$ (4.2-5.7 vs. $1.2-1.7$ ppm), and $\mathrm{Cu}$ (2.1-2.4 vs. $1.1-1.4 \mathrm{ppm})$, a result of the yard debris compost containing these nutrients and having a high $\mathrm{pH}$ and a low carbon to $\mathrm{N}$ ratio. In contrast, the soil under the sawdust topped with weed mat plots, that was not amended before planting, had a greater $\mathrm{NH}_{4}-\mathrm{N}$ (3.7-9.2 vs. 4.7-7.2 ppm) and $\mathrm{Al}$ (1208-1341 vs. 1110-1172 ppm) compared with the organic amendment-mulch treatment. There appeared to be little treatment effect on soil $\mathrm{NO}_{3}-\mathrm{N}, \mathrm{S}$, and $\mathrm{Fe}$ (data not shown).

Yield and fruiting season. The yield harvested was numerically quite different among the cultivars and sites, although without replication, no statistical comparison was possible (Table 2). 'Duke' had the lowest yield and 'Legacy' the highest at both sites. Yield increased from 2013 to 2014 at the organic site for all cultivars, except 'Aurora' (more fruit lost to sunburn in 2014), whereas yield declined for all cultivars except 'Duke' and 'Aurora' at the conventional site. All cultivars had a greater yield at the conventional site than the organic site in 2013 whereas 'Bluecrop', 'Legacy', and 'Liberty' had a greater yield at the organic site in 2014. The reported yields were typical for these mature cultivars grown on well-managed farms in this region.

The fruiting season varied not only among cultivars, as expected, but also among years and sites. At the organic site, the early and midseason cultivars had a longer picking season in 2014 than in 2013, whereas the opposite was found for the late-season cultivars. At the conventional site, all cultivars were picked longer in 2014 than in 2013. This was mainly because the grower decided to let the later ripening fruit on each cultivar remain on the plant longer ("hang") and then used a machine harvester to pick this fruit; this is a relatively common practice in this region. There was as much as a 3-month difference in the beginning of the earliest harvest of 'Duke' to the last harvest of 'Aurora' (Table 2). Considering the differences in yield and fruiting season observed, these cultivars were a good choice for assessing whether sampling time and leaf nutrient concentration standards should differ among cultivars commonly grown in the Pacific northwestern United States as stated in our objectives.

Fruit nutrients. Site had a significant effect on fruit N, K, and B and thus data are presented by site (Tables 4 and 5). Fruit from the organic site had lower concentration of $\mathrm{N}$ and $\mathrm{B}$ and higher $\mathrm{K}$ than fruit from the conventional site. Fruit $\% \mathrm{~N}$ decreased from 2013 to 2014 at both sites, despite average yield increasing from year 1 to year 2 at the organic site and decreasing at the conventional site. In addition, the rate of $\mathrm{N}$ fertilizer applied was similar among years at the organic site, but the rate was increased from 2013 to 2014 at the conventional site (Table 1). Thus, the relationship between yield and fertilizer rate and fruit $\% \mathrm{~N}$ appears to be complicated among these cultivars grown. There was no effect of amendment-mulch on fruit nutrient concentration at the organic site despite treatment effects on soil $\mathrm{N}$ and $\mathrm{K}$.

Cultivar had a significant effect on all fruit nutrients at the organic site and all but $\mathrm{P}$ at the conventional site. Fruit moisture content ranged from $82 \%$ to $87 \%$ (Table 4 ) and was affected by cultivar, but not site or year. Nitrogen $(0.5 \%$ to $0.7 \%)$ and K $(0.5 \%)$ accounted for the largest proportion of nutrient content in the fruit as has been reported by others in blueberry (Ballinger and Kushman, 1966) and in other fruit crops (e.g., in blackberry by Harkins et al., 2014). 'Aurora' tended to have the lowest fruit $\mathrm{N}$ at both sites. There was a year $\times$ cultivar interaction on fruit $\mathrm{K}$ at both sites (Table 4). At the organic site, fruit K in 'Draper' decreased from 2013 to 2014, whereas the opposite was found in 'Aurora'. The fruit K of 'Draper' also decreased from 2013 to 2014 at the conventional site. There was no clear pattern between changes in yield from year 1 to year 2 and fruit $\% \mathrm{~K}$ within the cultivars studied. 'Bluecrop' had the highest fruit $\mathrm{K}$ in both years at the organic site, whereas there were

Table 3. Mean daily average, minimum, and maximum air temperature and total precipitation Jan. to Dec. 2013-14 at the North Willamette Research and Extension Center, Aurora, OR. Weather data were obtained from a nearby AgriMet weather station (Aurora, OR) (U.S. Department of the Interior, 2013).

\begin{tabular}{|c|c|c|c|c|c|c|c|c|}
\hline \multirow[b]{2}{*}{ Month } & \multicolumn{2}{|c|}{ Mean air temp $\left({ }^{\circ} \mathrm{C}\right)$} & \multicolumn{2}{|c|}{ Minimum air temp $\left({ }^{\circ} \mathrm{C}\right)^{\mathrm{z}}$} & \multicolumn{2}{|c|}{ Maximum air temp $\left({ }^{\circ} \mathrm{C}\right)$} & \multicolumn{2}{|c|}{ Precipitation total $(\mathrm{mm})$} \\
\hline & 2013 & 2014 & 2013 & 2014 & 2013 & 2014 & 2013 & 2014 \\
\hline February & 6.6 & 5.1 & -0.9 & -7.7 & 17.0 & 18.1 & 36 & 145 \\
\hline May & 14.6 & 15.6 & 1.3 & 2.7 & 29.3 & 33.2 & 110 & 65 \\
\hline June & 17.7 & 16.7 & 6.5 & 7.1 & 34.6 & 29.8 & 33 & 36 \\
\hline July & 20.6 & 21.8 & 8.8 & 10.8 & 34.0 & 37.1 & 0 & 18 \\
\hline October & 10.8 & 14.7 & -0.8 & 6.8 & 25.0 & 29.9 & 26 & 172 \\
\hline November & 7.3 & 8.0 & -4.4 & -6.3 & 17.3 & 17.7 & 90 & 67 \\
\hline December & 2.1 & 7.1 & -12.4 & -3.8 & 13.1 & 17.8 & 48 & 173 \\
\hline Total/avg & 11.7 & 13.0 & 0.8 & 2.1 & 25.4 & 26.6 & 719 & 1,065 \\
\hline
\end{tabular}

${ }^{\mathrm{z}}$ Minimum recorded temperature is given for each winter month while maximum recorded temperature is given for each summer month. 


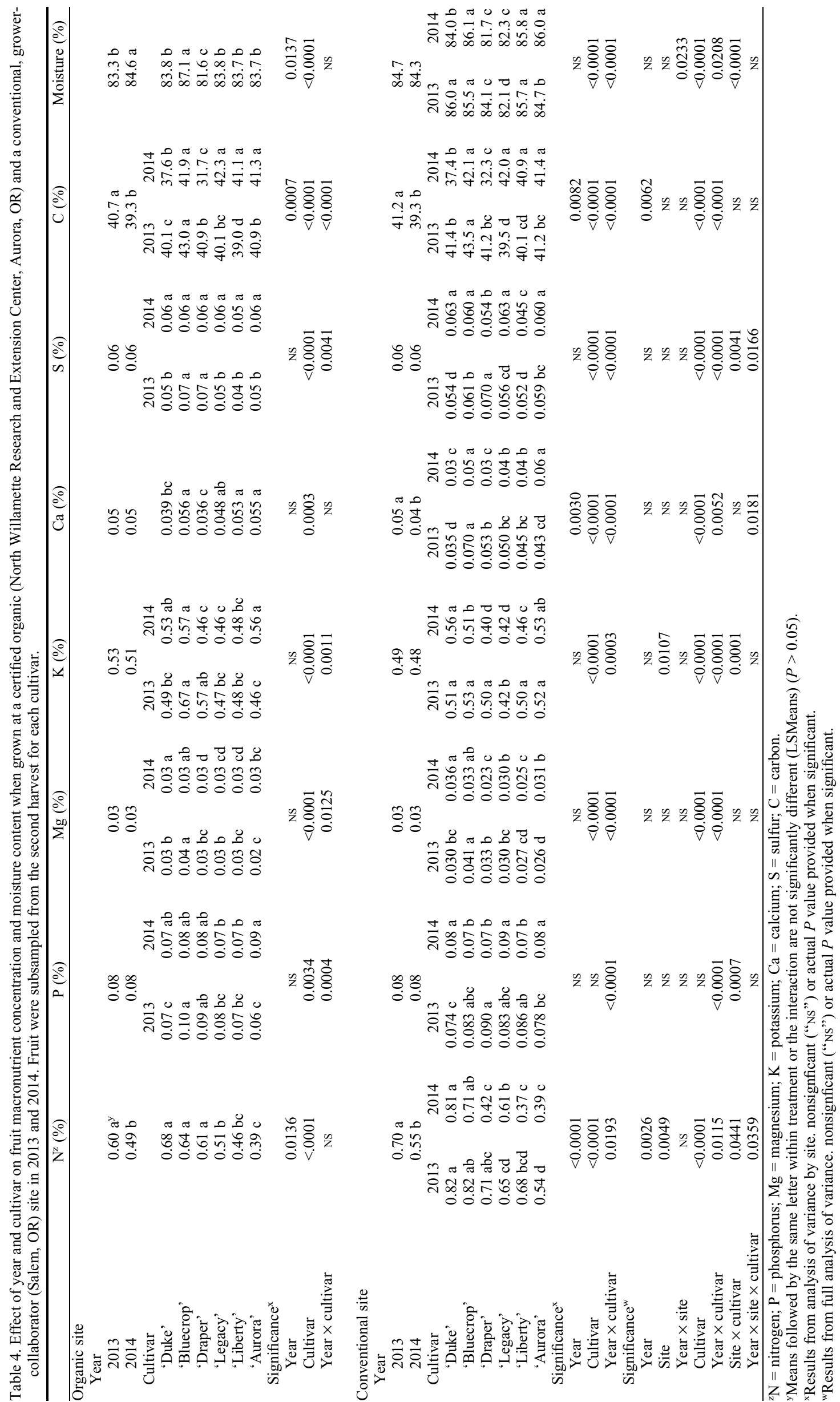


Table 5. Effect of year and cultivar on fruit micronutrient concentration when grown at a certified organic (North Willamette Research and Extension Center, Aurora, OR) and a conventional, grower-collaborator (Salem, OR) site in 2013 and 2014. Fruit were subsampled from the second harvest for each cultivar.

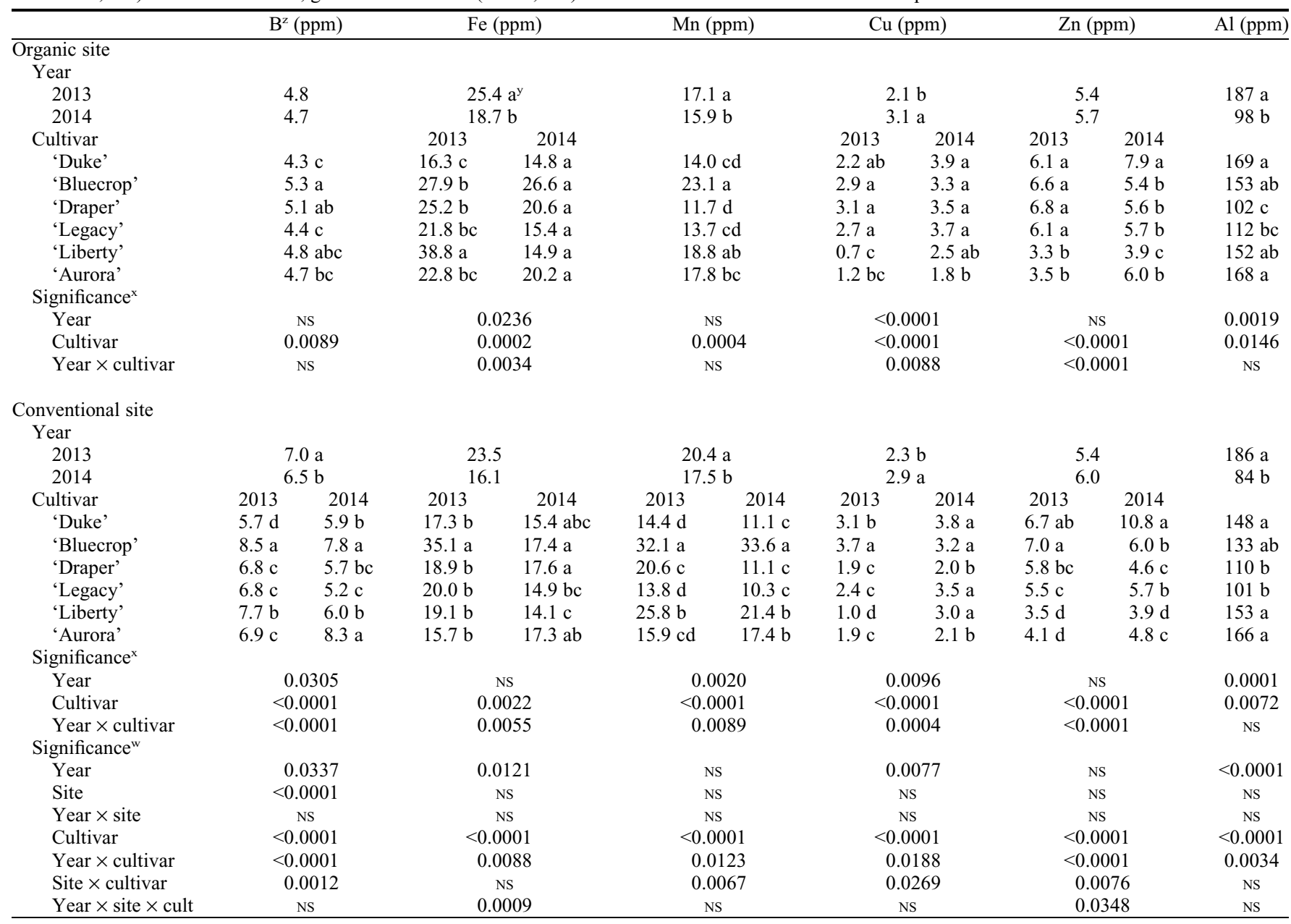

${ }^{\mathrm{z}} \mathrm{B}=$ boron; $\mathrm{Fe}=$ iron; $\mathrm{Mn}=$ manganese; $\mathrm{Cu}=$ copper; $\mathrm{Zn}=$ zinc; $\mathrm{Al}=$ aluminum

${ }^{\mathrm{y}}$ Means followed by the same letter within treatment or the interaction are not significantly different (LSMeans) $(P>0.05)$.

"Results from analysis of variance by site. nonsignficant ("NS") or actual $P$ value provided when significant.

${ }^{\text {w}}$ Results from full analysis of variance. nonsignficant ("NS") or actual $P$ value provided when significant.

fewer differences among cultivars at the conventional site.

Cultivars differed in fruit Ca concentration (Table 4). 'Draper' and 'Duke' had the lowest fruit $\mathrm{Ca}$ at the organic site and 'Draper' had particularly low fruit $\mathrm{Ca}$ at the conventional site in 2014. Fruit Ca content within a cultivar may be related to fruit quality in blueberry (Ochmian, 2012) as it is in other crops (Gerasopoulos and Drogoudi, 2005; Knee and Srivastava, 1995; Singh et al., 2006). Despite having low fruit Ca, 'Duke' and 'Draper' are considered relatively firm cultivars relative to the others studied and thus genetic factors appear more related to fruit firmness than $\mathrm{Ca}$ concentration.

Considering the yield (Table 2) and the macro- and micronutrient concentration in the fruit (Tables 4 and 5) nutrient removal in these cultivars ranged from 10 to $39 \mathrm{~kg} \cdot \mathrm{ha}^{-1}$ of $\mathrm{N}$ at the organic site and 10 to $52 \mathrm{~kg} \cdot \mathrm{ha}^{-1}$ of $\mathrm{N}$ at the conventional site. Removal of $\mathrm{K}$ in the fruit ranged from 7 to $31 \mathrm{~kg} \cdot \mathrm{ha}^{-1}$ and 13 to $34 \mathrm{~kg} \cdot \mathrm{ha}^{-1}$ at the organic and conventional site, respectively. From 6 to $55 \mathrm{~g} \cdot \mathrm{ha}^{-1}$ of $\mathrm{B}, 9$ to $44 \mathrm{~g} \cdot \mathrm{ha}^{-1}$ of $\mathrm{Zn}, 22$ to $158 \mathrm{~g} \cdot \mathrm{ha}^{-1}$ of $\mathrm{Mn}$, and 0.2 to $1.1 \mathrm{~kg} \cdot \mathrm{ha}^{-1}$ of $\mathrm{Al}$ was removed, depending on cultivar, site, and year. These values are estimates based on fruit nutrient content on the second harvest date of each cultivar. However, fruit nutrient concentration may be affected by fruit harvest date as found in 'Wolcott' (Ballinger and Kushman, 1966). Fruit nutrient removal from the field would be affected by fruit nutrient concentration and yield. In a high-yielding cultivar such as 'Legacy' the removal of $\mathrm{N}$ and $\mathrm{K}$ in the fruit was as much as 4-fold greater than the lowest yielding cultivars in our study (Tables 2 and 4).

Fruit had a carbon concentration ranging from $32 \%$ to $44 \%$ depending on cultivar and year (Table 4 ) similar to the $41 \%$ reported for blueberry cv. Elliott by Nemeth (2013). The amount of carbon removed in harvested fruit thus ranged from 0.5 to $3.2 \mathrm{t} \cdot \mathrm{ha}^{-1}$, depending on cultivar and year. 'Legacy' had a particularly high calculated carbon stock in fruit (as high as $3.2 t \cdot h^{-1}$ ). Nemeth (2013) reported C stocks of $1.1 \mathrm{~kg} \cdot \mathrm{ha}^{-1}$ in harvested fruit of 'Elliott'.

Full analysis of year, site, and cultivar effects for leaf nutrients. When the complete set of leaf tissue nutrient data were analyzed by sample date with year as the main effect $(\mathrm{n}=2)$, site as the sub-plot plot effect $(\mathrm{n}=2)$, and cultivar as the sub-subplot effect $(n=6)$, there were significant year, site, cultivar, year $\times$ site, year $\times$ cultivar, and site $\times$ cultivar interactions for all nutrients on most sample dates through the season $(\mathrm{n}=13)$. In addition, there was a year $\times$ site $\times$ cultivar interaction on some sample dates for many nutrients (data not shown).

Year and site effects. The effect of year and site (year $\times$ site) on leaf macro- and micronutrient concentration as affected by tissue sampling date is shown in Figs. 1 and 2, respectively, averaged over cultivar. In spring, leaf $\mathrm{N}, \mathrm{P}, \mathrm{K}, \mathrm{S}, \mathrm{Mn}, \mathrm{Cu}$, and $\mathrm{Zn}$ declined with a significant year $\times$ site interaction on several sampling dates from 22 Apr. through 14 June for many of these nutrients. Leaf nutrient concentration either continued to decline for the rest of the growing season $(\mathrm{N}$ and $\mathrm{Cu})$, remained relatively stable in the latter part of the season $(\mathrm{P}, \mathrm{K}, \mathrm{S}$, and $\mathrm{Zn})$, or increased in the latter part of the season (Mn). Leaf $\mathrm{Mg}, \mathrm{Ca}, \mathrm{Al}$, and $\mathrm{B}$ changed relatively little from the earliest sample date to mid-June, but then increased 

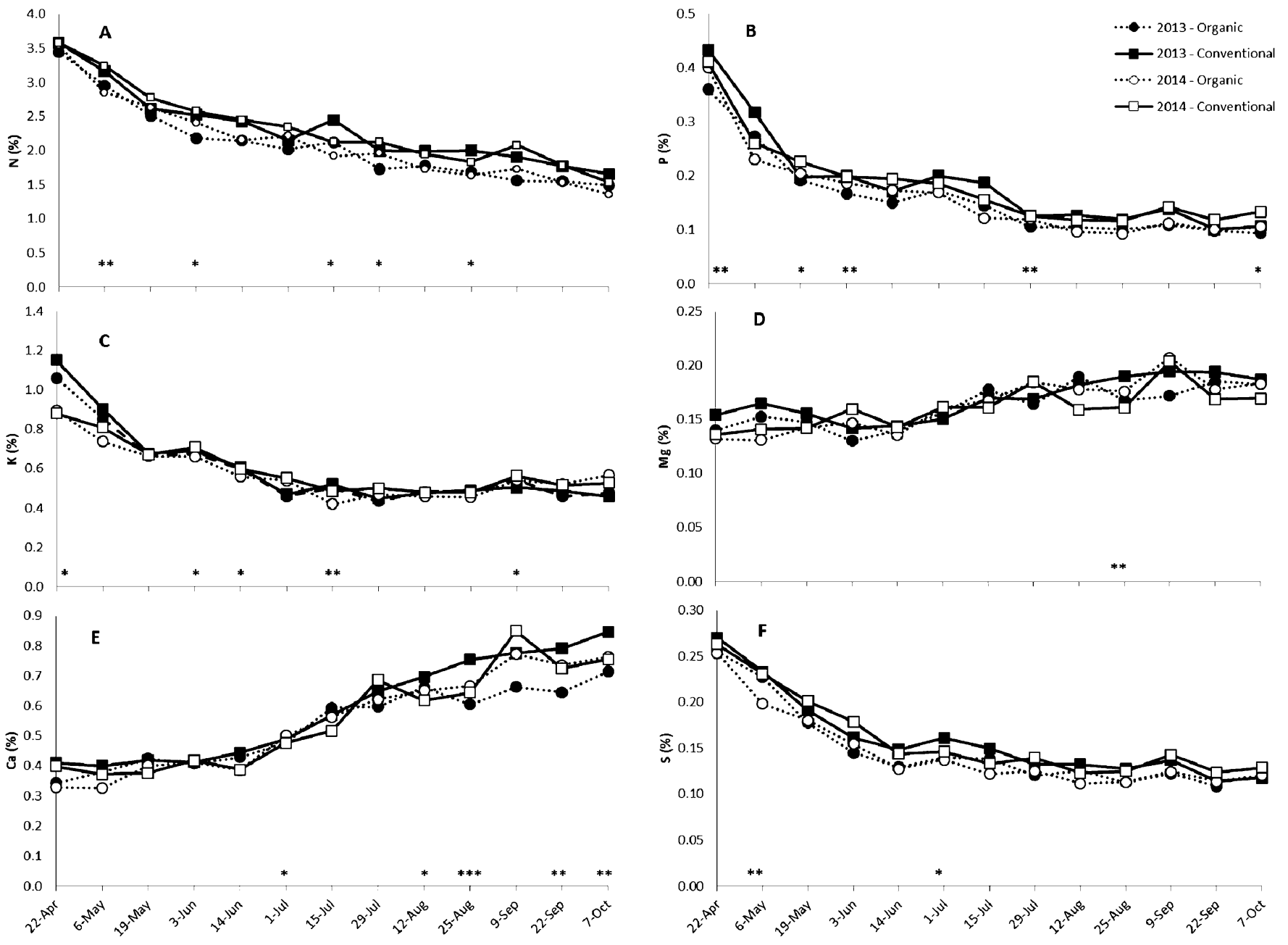

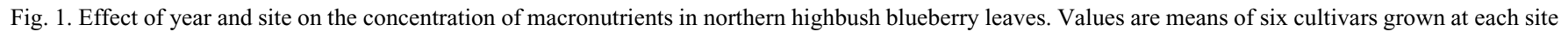
and amendment-mulch at the organic site. "Organic" = certified, organic blueberry site at the North Willamette Research and Extension Center, Aurora, OR; "Conventional" = conventionally managed grower-collaborator site, Salem, OR. $\mathbf{A}=$ nitrogen; $\mathbf{B}=$ phosphorus; $\mathbf{C}=$ potassium; $\mathbf{D}=$ magnesium; $\mathbf{E}=$ calcium; $\mathbf{F}=$ sulfur. The interaction of year $\times$ site is significant at $* P \leq 0.05, * * P \leq 0.01, * * * P \leq 0.001$, and $* * * * P \leq 0.0001$.

slightly $(\mathrm{Mg})$ or greatly $(\mathrm{Ca}, \mathrm{Al}$, and $\mathrm{B})$ for the rest of the growing season (Figs. 1 and 2).

Our findings for changes in leaf $\mathrm{N}, \mathrm{P}, \mathrm{Mg}$, and $\mathrm{Ca}$ through the season are similar to those reported for northern highbush blueberry cv. Rubel in Massachusetts (Bailey et al., 1962) and cv. Jersey in North Carolina (Chuntanaparb and Cummings, 1980) and for rabbiteye blueberry (Vaccinium virgatum Aiton) cv. Tifblue in Mississippi (Spiers, 1982). However, our findings disagree with those of Clark et al. (1989) who reported little change in leaf $\mathrm{Ca}, \mathrm{Mg}, \mathrm{S}$, or $\mathrm{Zn}$ in 'Bluecrop' over various sample dates in diverse commercial fields in Arkansas.

In our study, despite relatively large differences in management and yield, the pattern in leaf nutrient concentration over sampling time was relatively similar between sites and years. Bailey et al. (1962) found a significant effect of year on many measured leaf nutrients in 'Rubel', but reported the trends between years were very similar.

Amendment-mulch effect, organic site. Preplant amendment and surface mulch type at the organic site only had a significant effect on leaf $\mathrm{Mn}$ and $\mathrm{Al}$ (Fig. 3). While there was a significant cultivar $\times$ mulch interaction on one sample date for leaf Mn (23 Apr. 2013), there were more for leaf $\mathrm{Al}$ concentration (4 of 13 sample dates in 2013 and 2 dates in 2014). However, there were no consistent cultivar differences among these sample dates (data not shown). Leaf $\mathrm{Mn}$ and $\mathrm{Al}$ concentrations were higher when plants were grown with weed mat than with organic mulch on most sample dates in 2013-14 (Fig. 3), because soil $\mathrm{pH}$ was lower under weed mat (5.3 in Oct. 2014) than when preplant amendment and organic mulch were used (6.2). The soil $\mathrm{pH}$ in the organic mulch treatment was above that recommended for blueberry (4.5-5.5; Hart et al., 2006), likely a result of the preplant incorporation of the yard debris compost which had a $\mathrm{pH}$ of 7.5 (data not shown). Clark et al. (1989) found that mulch increased soil $\mathrm{pH}$ relative to bare soil and increased leaf $\mathrm{Ca}$. In our study, we found no effect of mulch type on leaf $\mathrm{Ca}$, despite the high $\mathrm{Ca}$ content of the compost and resulting increase in soil $\mathrm{Ca}$ in this treatment. In addition, there was no amendment-mulch effect on leaf $\mathrm{K}$ or $\mathrm{N}$ despite differences in soil $\mathrm{N}$ and $\mathrm{K}$ in autumn.
The $\mathrm{N}$ released from the compost and the $\mathrm{K}$ may not be readily available to the plants at the period of greatest demand for shoot growth.

Cultivar effects at each site. The effect of cultivar on leaf tissue nutrient concentration over the 2013 growing season is shown in Figs. 4-7. The pattern of change in each nutrient over the season was quite similar between 2013 and 2014 (Figs. 1 and 2; cultivar data for 2014 not shown) with some notable exceptions: 1) leaf $\mathrm{N}$ concentration at the conventional site was greater in 2014 than in 2013, likely a result of the grower applying a greater rate of $\mathrm{N}$ fertilizer (Table 1); and 2) leaf $\mathrm{Zn}$ was higher on some sample dates at the conventional site in 2014 , because the grower applied a fungicide containing $\mathrm{Zn}$ $\left(\right.$ Ziram $^{\circledR}, 16.25 \%$ Zn; United Phosphorus, Inc., King of Prussia, PA). We therefore chose to present the results for 2013 in Figs. 4-7.

There was a significant effect of cultivar on leaf $\mathrm{N}$ concentration on many sample dates at the conventional site (Fig. 4), but not at the organic site (Fig. 5). 'Liberty' had the highest leaf $\mathrm{N}$ throughout much of the 

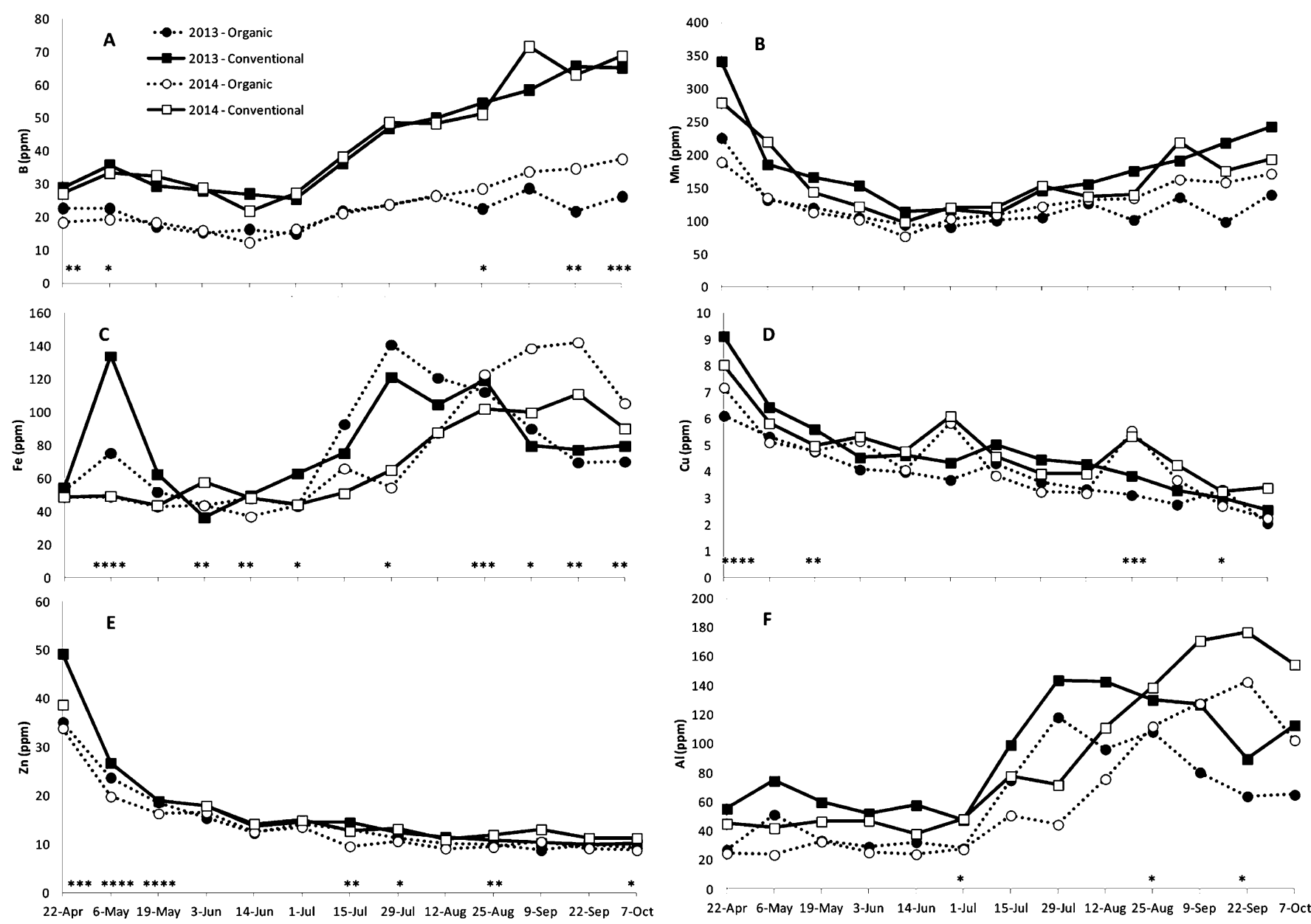

22-Apr 6-May 19-May 3-Jun 14-Jun 1-Jul 15-Jul 29-Jul 12-Aug 25-Aug 9-Sep 22-Sep 7-Oct

Fig. 2. Effect of year and site on the concentration of micronutrients in northern highbush blueberry leaves. Values are means of six cultivars grown at each site and amendment-mulch at the organic site. "Organic" = certified, organic blueberry site at the North Willamette Research and Extension Center, Aurora, OR; "Conventional" = conventionally managed grower-collaborator site, Salem, OR. A = boron; $\mathbf{B}=$ manganese; $\mathbf{C}=$ iron; $\mathbf{D}=$ copper; $\mathbf{E}=$ zinc; $\mathbf{F}=$ aluminum. The interaction of year $\times$ site is significant at $* P \leq 0.05,{ }^{*} P \leq 0.01,{ }^{* * *} P \leq 0.001$, and $* * * * P \leq 0.0001$.

season at the conventional site. Leaf $\mathrm{N}$ leveled off in the late July to mid-August period, regardless of cultivar or fruiting season. Our findings agree with those reported by Bailey et al. (1962) in 'Rubel'; however, they speculated that leaf $\mathrm{N}$ leveled off during this period, because this was the fruit ripening period. This is likely not the case as all cultivars leveled off at this time regardless of fruiting season (Table 2).

In the spring, 'Legacy' had lower leaf N, $\mathrm{Mg}, \mathrm{Ca}$, and $\mathrm{S}$ than most other cultivars at both sites (except for $\mathrm{N}$ at the organic site). It is possible that 'Legacy' had different leaf nutrient concentrations than the other cultivars on many sampling dates, because this is the only cultivar studied with a significant percentage of southern highbush blueberry (Vaccinium darrowii Camp.) in its parentage. 'Legacy' and 'Bluecrop' had a lower leaf K than most other cultivars in spring at both sites. There were relatively large differences among cultivars in leaf $\mathrm{Mg}, \mathrm{Ca}$, and $\mathrm{K}$ when leaves were sampled from approximately midJuly to autumn at both sites (Figs. 4 and 5). 'Duke' and 'Bluecrop' tended to have the highest leaf $\mathrm{K}$ during this period, whereas 'Legacy' and 'Liberty' had the lowest. 'Bluecrop' also had the highest fruit $\mathrm{K}$ and 'Legacy' and 'Liberty' were amongst the lowest in fruit $\mathrm{K}$ (Table 4). The pattern of changes in leaf $\mathrm{K}$ over the season disagree with that reported by Bailey et al. (1962) who found that leaf K declined from spring to midsummer and then increased to levels higher than those measured in spring. They speculated that $\mathrm{K}$ accumulated in leaves after fruit harvest. While we did observe a slight increase in leaf $\mathrm{K}$ from the lowest levels measured at the beginning of July to leaf senescence (Figs. 4 and 5), all cultivars accumulated leaf $\mathrm{K}$ at about the same time. Also, while early- and midseason fruiting cultivars such as 'Duke' and 'Bluecrop' did have the highest leaf $\mathrm{K}$ in late season, so did 'Aurora' which was fruiting at that time. Spiers (1982) reported that the best time to sample 'Tifblue' rabbiteye blueberry for leaf $\mathrm{K}$ was during fruiting when levels were most stable. In the diverse northern highbush blueberry cultivars studied here, this was not the case.

'Bluecrop' and 'Draper' had the greatest leaf $\mathrm{Mg}$ at the conventional site and were amongst the highest at the organic site. 'Aurora' had the lowest leaf Mg at both sites. The differences between cultivars in leaf $\mathrm{Mg}$
(Figs. 4 and 5) were relatively large compared with what was observed in fruit (Table 4).

There were greater differences in leaf $\mathrm{Ca}$ among cultivars at the conventional site than at the organic site. At both sites, 'Draper' and 'Legacy' had higher leaf Ca than 'Duke'. Leaf $\mathrm{Ca}$ in 'Draper' was much higher at the conventional site than at the organic site. Considering that 'Draper' had the highest leaf $\mathrm{Ca}$ (Table 6) and amongst the lowest fruit $\mathrm{Ca}$ (Table 4), it is possible that new shoot growth may be a sink for $\mathrm{Ca}$ in some cultivars, thus reducing fruit $\mathrm{Ca}$. The grower at the conventional site fertilized with a higher rate of $\mathrm{N}$ in 2014 than in 2013 (Table 1), leading to an increase in leaf $\mathrm{Ca}$ in 2014. However, higher rates of $\mathrm{N}$ fertilizer have been found to reduce leaf $\mathrm{Ca}$ (Ballinger and Kushman, 1966; Spiers, 1983) and fruit $\mathrm{Ca}$ (Ballinger and Kushman, 1966) in blueberry. The higher rate of $\mathrm{N}$ at the conventional site in 2014 may have increased vigor in 'Draper', reducing fruit $\mathrm{Ca}$. There did not appear to be a negative correlation between leaf $\mathrm{Ca}$ and fruit $\mathrm{Ca}$ among the cultivars, indicating there may be genetic differences for growth and $\mathrm{Ca}$ allocation within the plant. 

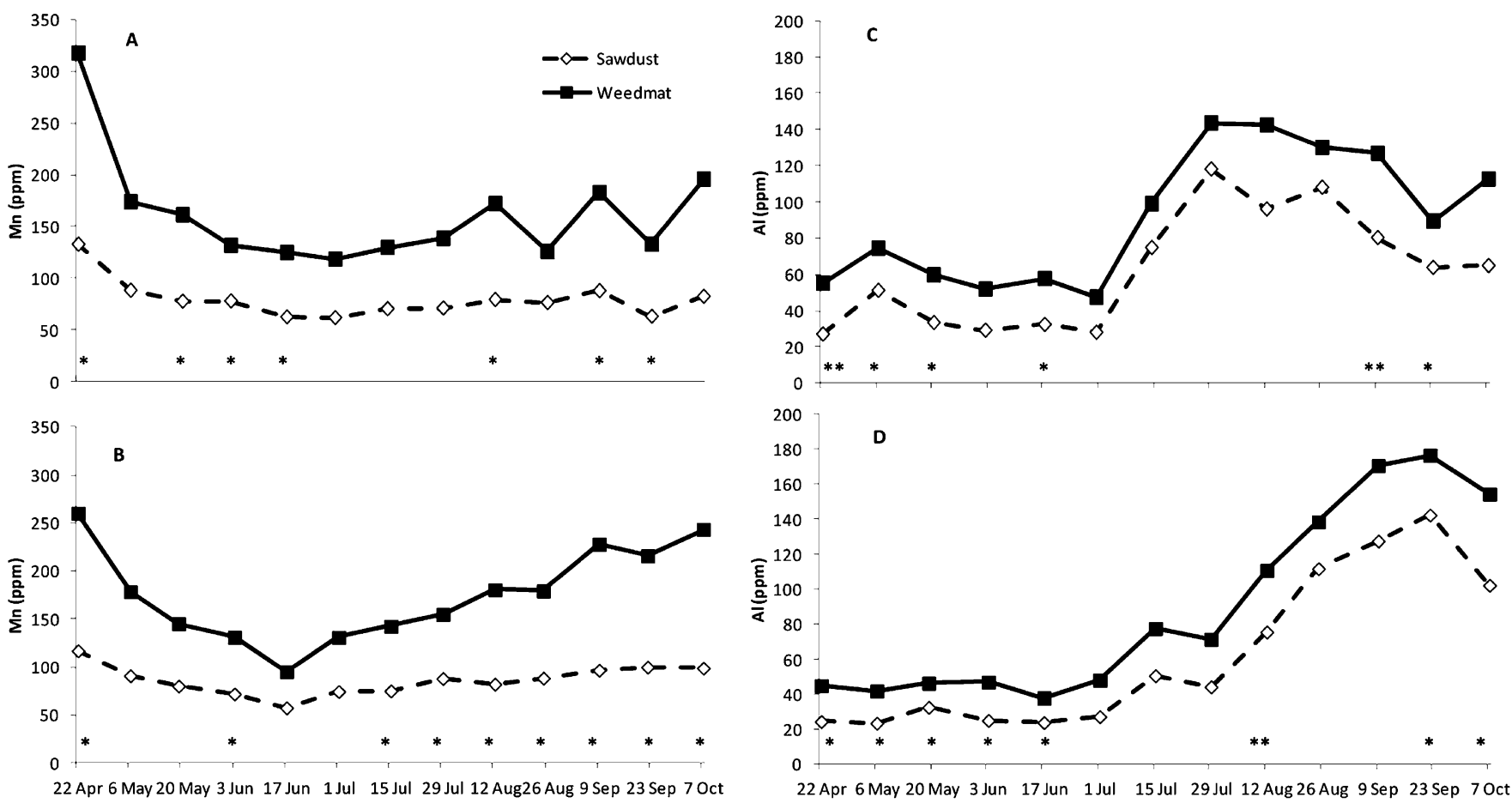

Fig. 3. Effect of amendment-mulch treatment on the concentration of leaf manganese (Mn) in 2013 (A) and 2014 (B) and leaf aluminum (Al) in 2013 (C) and 2014 (D) at the certified, organic blueberry site, North Willamette Research and Extension Center, Aurora, OR. Values are the mean of six cultivars. "Sawdust" = preplant amendment with yard debris compost and sawdust and mulched with both products; "weedmat" = no preplant amendment and mulched with sawdust topped with permeable, black, polyethylene groundcover. The main effect of amendment-mulch is significant at $* P \leq 0.05,{ }^{* *} P \leq 0.01, * * * P \leq 0.001$, and $* * * * P \leq 0.0001$.

There were larger differences among cultivars in leaf micronutrient concentration throughout the season at the conventional site (Fig. 6) than at the organic site (Fig. 7). The soil at the conventional site ranged from $\mathrm{pH} 4.0$ in 'Bluecrop' to $\mathrm{pH} 5.4$ in 'Legacy' (data not shown). 'Bluecrop' had a higher leaf $\mathrm{Mn}, \mathrm{Al}$, and $\mathrm{Fe}$ on many sample dates and leaf $\mathrm{B}$ in the late season than the other cultivars at the conventional site (Fig. 6), but only had slightly higher leaf $\mathrm{Mn}$ at the organic site (Fig. 7). Leaf $\mathrm{Fe}$ and $\mathrm{Al}$ in 'Bluecrop' may have been more variable at the conventional site than for the other cultivars because this cultivar was irrigated by sprinklers, potentially causing more contamination from soil/dust on leaves before analysis. Leaf B was low at the organic site likely due to low soil B $\left(<0.5 \mathrm{mg} \cdot \mathrm{kg}^{-1}\right)$.

Leaf carbon. Leaf carbon (C) averaged $\approx 52 \%$ of dry weight on the first sample date at bloom and declined slightly to $\approx 48 \%$ to $50 \%$ in mid-June to 1 July, depending on site and year (data not shown). In mid-July to the end of July, depending on year, leaf $\mathrm{C}$ increased to $\approx 54 \%$, after which it declined again to an average of $50 \%$; the peak of this shift was 1 week later in 2014 than in 2013 leading to a significant difference in leaf $\mathrm{C}$ in late July (Table 6). By the end of the season, in September, leaf $\mathrm{C}$ averaged $52 \%$ again (data not shown). The reason for these changes in leaf $\mathrm{C}$ is not clear as all cultivars followed the same pattern regardless of fruiting season. 'Legacy' had a greater leaf $\mathrm{C}$ at both sites on most sample dates (data not shown), including in late July (Table 6), which was particularly interesting considering this cultivar also had the greatest $\mathrm{C}$ stock in harvested fruit (see above). Our results are similar to what was reported for 'Elliott' (leaf $\mathrm{C}$ averaged $52 \%$ over two seasons) by Nemeth (2013).

Recommended leaf sampling date. The current recommended leaf tissue sampling time to compare plant nutrient status to published sufficiency levels is in late July to early August (Hart et al., 2006). In our study, the measured leaf nutrient concentrations were within the current published sufficiency levels on many sample dates throughout the season for $\mathrm{P}, \mathrm{Mg}, \mathrm{S}, \mathrm{Mn}$, and $\mathrm{Zn}$, on many dates in midseason for $\mathrm{K}$ and $\mathrm{Ca}$, and from mid to late-season for B and Fe (Figs. 4-7). However, leaf $\mathrm{N}$ was only within the recommended standards when sampled in late-July to early August, agreeing with Clark et al. (1989). Leaf nutrient concentrations were relatively stable when sampling from late July to late August for most nutrients. However, leaf $\mathrm{Ca}$ and $\mathrm{B}$ (particularly at the conventional site) was increasing during this period for many cultivars. Leaf $\mathrm{Mg}$ was also variable during this period for some cultivars. While, there was thus no period where all nutrients were relatively stable, the current recommended period of late July to early August remains a good compromise based on our findings.

When leaf sampling dates of 30 July and 12 Aug. were compared along with year and cultivar effects at each site, there was a significant effect $(P \leq 0.05)$ of leaf sample date, year, and cultivar as well as many interactions at each site (data not shown). At the organic site, leaf $\mathrm{N}, \mathrm{P}, \mathrm{S}$, and $\mathrm{Zn}$ were higher in leaves when sampled on 30 July than on 12 Aug., whereas the opposite was found for leaf $\mathrm{Mg}$, $\mathrm{K}, \mathrm{Ca}$, and $\mathrm{B}$. At the conventional site, leaf $\mathrm{N}$, $\mathrm{S}$, and $\mathrm{Zn}$ were higher when sampled on 30 July than on 12 Aug., but the opposite was found for leaf Al. Leaf nutrient concentrations, when averaged over cultivar, were within the current recommended standards (Hart et al., 2006) for both sample dates, except for a lower leaf $\mathrm{N}, \mathrm{P}, \mathrm{B}$ and $\mathrm{Cu}$ (on both sample dates) when sampled on 12 Aug. at the organic site and a lower leaf $\mathrm{Cu}$ (on both sample dates) and a higher leaf $\mathrm{N}$ when sampled on 30 July at the conventional site. We have presented the results for leaf tissue sampling at the end of July in Table 6.

At the organic site, there was a significant effect of cultivar on leaf $\mathrm{P}, \mathrm{Mg}, \mathrm{K}, \mathrm{Ca}, \mathrm{S}, \mathrm{B}$, $\mathrm{Mn}, \mathrm{Cu}$, and $\mathrm{Zn}$ and a year $\times$ cultivar interaction on leaf $\mathrm{Mg}$ and $\mathrm{Ca}$ (Table 6). At the conventional site, cultivar had a significant effect on all leaf nutrients except for $\mathrm{S}$. There was also a year $\times$ cultivar effect on leaf $\mathrm{Mg}$, $\mathrm{K}, \mathrm{Fe}$, and Al. Eaton and Meehan (1971) found that 11 cultivars of northern highbush blueberry grown in British Columbia, Canada (none of which were the same as the ones we studied) differed in most leaf nutrients in August when plants were unfertilized.

Leaf P levels were at the low end of the current sufficiency range at both sites, with 'Bluecrop' and 'Aurora' having the highest leaf $P$. While leaf $P$ was just below the lower end of the sufficiency range, there was no evidence of $\mathrm{P}$ deficiency and soil $\mathrm{P}$ was well 

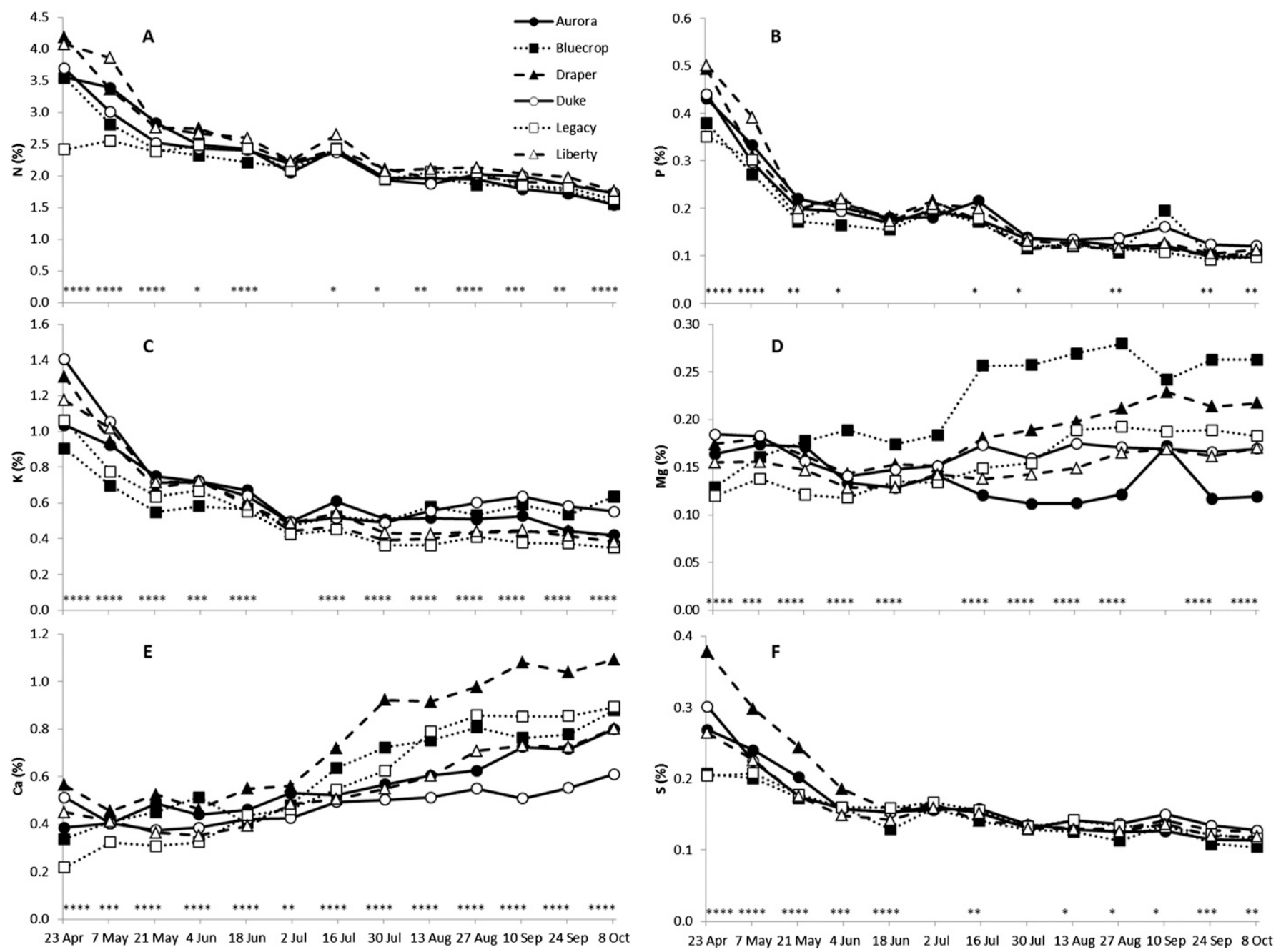

Fig. 4. Effect of cultivar on the concentration of macronutrients in leaves when sampled over the growing season in 2013 at the conventionally managed growercollaborator site, Salem, OR. A = nitrogen; $\mathbf{B}=$ phosphorus; $\mathbf{C}=$ potassium; $\mathbf{D}=$ magnesium; $\mathbf{E}=$ calcium; $\mathbf{F}=$ sulfur. The main effect of cultivar is significant at $* P \leq 0.05, * * P \leq 0.01, * * * P \leq 0.001$, and $* * * * P \leq 0.0001$.

above recommended levels. In other northern highbush blueberry studies, leaf $\mathrm{P}$ was either below current sufficiency levels or borderline low $(0.11 \%$ P) (Bailey et al., 1962; Chuntanaparb and Cummings, 1980; Eaton and Meehan, 1971), whereas Spiers (1982) reported higher leaf $\mathrm{P}(0.15 \%)$ at this sampling time in 'Tifblue' rabbiteye blueberry. Floricane(Archbold et al., 1989; Clark et al., 1988; Naraguma and Clark, 1998) and primocanefruiting (Strik, 2015) blackberry cultivars were also reported to have a leaf $\mathrm{P}$ below recommended sufficiency levels when sampled in late July/early August.

Even though leaf $\mathrm{N}$ was significantly lower in 2013 than in 2014 at both sites, it was barely below current sufficiency levels only at the organic site (Table 6). Leaf N may have increased at the conventional site as more N fertilizer was applied in 2014 (Table 1), since leaf $\mathrm{N}$ is positively correlated with fertilization rate in blueberry (Bañados et al., 2012; Retamales and Hanson, 1990; Spiers, 1983). There was no cultivar effect on leaf $\mathrm{N}$ at the organic site, whereas 'Draper' had a higher leaf $\mathrm{N}$ than all other cultivars at the conventional site.
Leaf $\mathrm{K}$ was highest in 'Duke' and 'Aurora' and lowest in 'Legacy' at the organic site. At the conventional site, 'Legacy' had the lowest leaf K in 2013, whereas 'Legacy', 'Liberty', and 'Draper' all had a lower leaf K in 2014 than the other cultivars. Leaf $\mathrm{K}$ of 'Legacy' was below the current recommended sufficiency levels at the organic site and in 2013, along with 'Draper', at the conventional site. Leaf $\mathrm{K}$ may be lower in 'Legacy', because it has such a high yield (Table 2). Leaf $\mathrm{N}$ and $\mathrm{K}$ have been reported to be negatively correlated with yield of 'Wolcott' (Ballinger, 1966; Ballinger and Kushman, 1966; Ballinger et al., 1963). However, other than for leaf $\mathrm{K}$ and yield in 'Legacy' we found no clear relationship between yield and leaf $\mathrm{K}$ among cultivars, although statistical analysis was not possible (Tables 2 and 6).

There was a year $\times$ cultivar effect on leaf $\mathrm{Mg}$ at both sites mainly because some cultivars showed an increase in leaf $\mathrm{Mg}$ from 2013 to 2014 whereas others remained the same (Table 6). 'Aurora' and 'Bluecrop' tended to have the highest leaf $\mathrm{Mg}$ at both sites, whereas 'Draper' had a similar leaf $\mathrm{Mg}$ to 'Bluecrop' only at the organic site. The leaf $\mathrm{Mg}$ measured in our study was similar to what has been reported elsewhere at the same sampling time (Bailey et al., 1962; Clark et al., 1989).

There was a year $\times$ cultivar effect on leaf $\mathrm{Ca}$ at the organic site because most cultivars had a similar leaf $\mathrm{Ca}$ between years whereas the leaf Ca of 'Aurora' decreased from 2013 to 2014. 'Draper' had the highest leaf $\mathrm{Ca}$ at both sites and was above current sufficiency levels at the conventional site. Leaf $\mathrm{Ca}$ was reportedly lower for 'Rubel' at this same time of year $(0.23 \%$ to $0.27 \%)$ in Michigan (Bailey et al., 1962), but Clark et al. (1989) in Arkansas reported similar leaf $\mathrm{Ca}$ in 'Bluecrop' in August. Leaf $\mathrm{Ca}$ was not apparently related to fruit $\mathrm{Ca}$ among cultivars (Tables 4 and 6).

The only cultivar with leaf B within the recommended sufficiency range at the organic site was 'Bluecrop' (Table 6). At the conventional site, only 'Liberty' and 'Aurora' had a leaf B below sufficiency levels. Soil B was low at these sites as mentioned previously, and foliar B was not applied during the study period. 'Aurora' had the lowest leaf $B$ at both sites. 

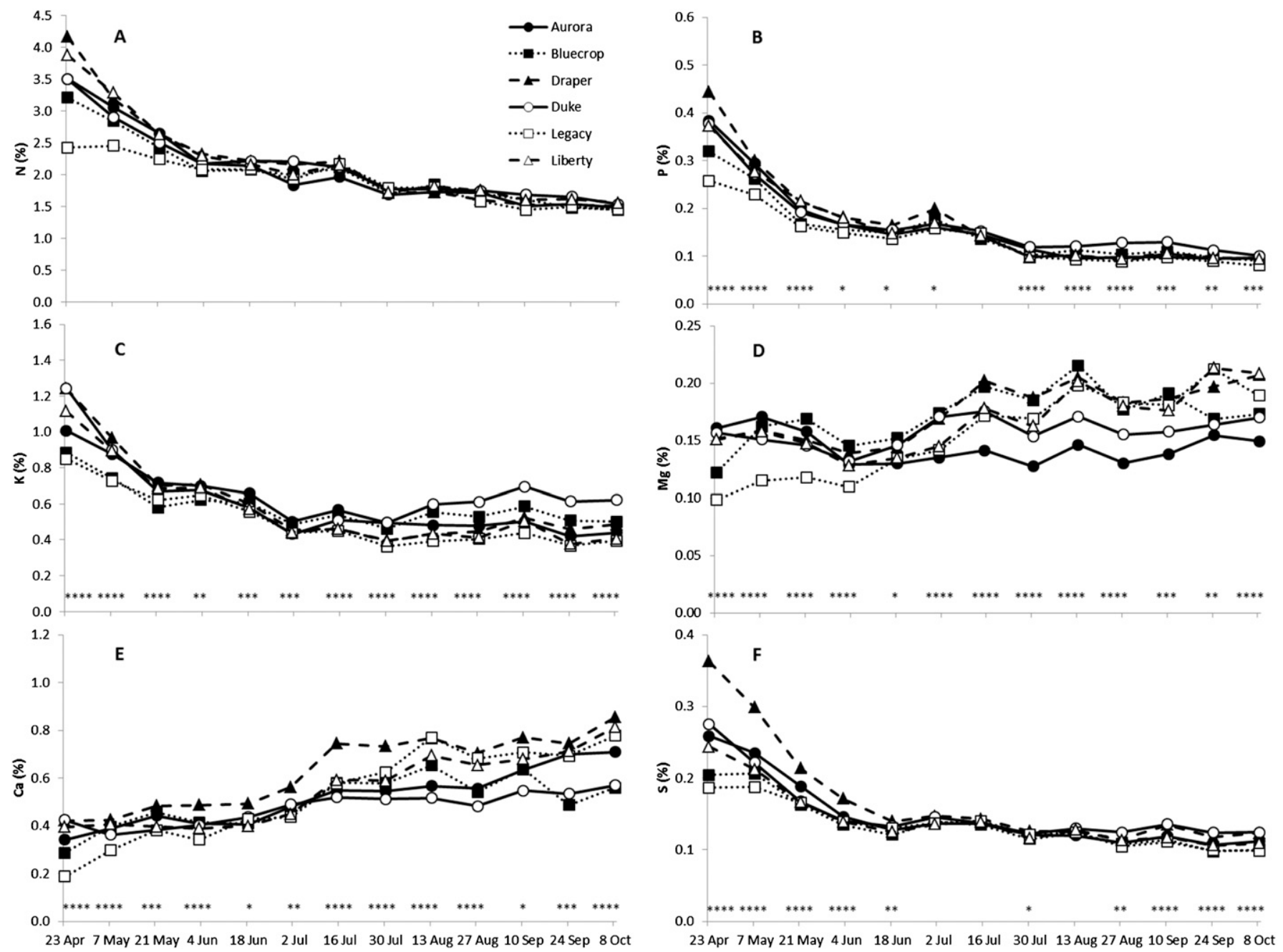

Fig. 5. Effect of cultivar on the concentration of macronutrients in leaves when sampled over the growing season in 2013 at the certified, organic blueberry site, North Willamette Research and Extension Center, Aurora, OR. Averaged over mulch type. $\mathbf{A}=$ nitrogen; $\mathbf{B}=$ phosphorus $; \mathbf{C}=$ potassium; $\mathbf{D}=$ magnesium; $\mathbf{E}=$ calcium; $\mathbf{F}=$ sulfur. The main effect of cultivar is significant at $* P \leq 0.05, * * P \leq 0.01, * * * P \leq 0.001$, and $* * * * P \leq 0.0001$.

Leaf Fe levels were very variable among sites and years, likely due to the presence of some dust on leaves that were not washed before analysis. Leaf $\mathrm{Fe}$ was higher, on average, at the conventional site where there was bare soil in the row, as compared with weed mat or organic mulch at the organic site (Figs. 6 and 7). Leaves were not washed before analysis per standard recommendation (Hart et al., 2006). 'Bluecrop' had the highest leaf Fe at the conventional site in both years, likely due to sprinkler irrigation increasing the amount of dust on leaves, as mentioned previously (Table 6).

Leaf $\mathrm{Cu}$ was lower than current sufficiency levels in all cultivars and sites except for 'Legacy' at the conventional site. 'Legacy' had higher leaf $\mathrm{Cu}$ than the other cultivars at both sites. Leaf $\mathrm{Zn}$ was higher in 'Duke' and 'Legacy' than in the other cultivars at both sites, whereas 'Liberty' had particularly low leaf $\mathrm{Zn}$ at the conventional site. There are no published sufficiency levels for leaf $\mathrm{Al}$ which was unaffected by cultivar at the organic site. Leaf $\mathrm{Al}$ was greater in 'Duke', 'Bluecrop', and 'Draper' than the other cultivars at the conventional site; again levels may have been higher as a result of dust contamination on leaves.
Leaf Mn was affected by cultivar at both sites with 'Aurora' having particularly low levels (Table 6). At the conventional site, leaf Mn may have been higher in 'Bluecrop', because this cultivar was growing in a $4.0 \mathrm{pH}$ soil. However, soil $\mathrm{pH}$ did not appear to be solely related to leaf Mn levels as 'Aurora', which had the lowest leaf Mn, was growing in a similar soil $\mathrm{pH}$ (4.5) to that of 'Draper' $(\mathrm{pH}$ 4.7) which had significantly higher leaf $\mathrm{Mn}$. While soil conditions, particularly $\mathrm{pH}$, affect leaf $\mathrm{Mn}$ and leaf $\mathrm{Al}$ (Fig. 3), there also appear to be cultivar differences in leaf $\mathrm{Mn}$ and $\mathrm{Al}$ under some conditions or sites (Table 6).

Based on our results, sampling cultivars separately for tissue analysis in late July to early August would still be advised to better manage nutrient programs (Hart et al., 2006). While the magnitude of the difference among blackberry cultivars may depend on how different they are genetically (Clark et al., 1988), this did not appear to be the case in our study — of the those studied here, 'Duke' is a parent of 'Liberty' and 'Aurora', for example, yet these cultivars differed considerably in leaf and fruit nutrient content. The magnitude of the difference in leaf nutrients among cultivars at the recommended sampling time may thus depend on how they respond to available soil and fertilizer nutrients and in the amount of nutrient allocated to fruit, particularly for $\mathrm{N}$ and $\mathrm{K}$, as related to fruiting season.

\section{Conclusions}

The findings of this study indicate that the best sampling time to determine plant nutrient status in northern highbush blueberry should remain the late July to mid-August period (Hart et al., 2006) when most nutrients were relatively stable, regardless of cultivar or fruiting season. Sampling cultivars after harvest, as recommended in the southeastern United States (Krewer et al., 2007) is not recommended in the Pacific northwestern region because many of the mid- to lateseason cultivars studied naturally have leaf tissue levels outside the current recommended standards after fruit harvest. All cultivars studied followed a similar pattern in leaf nutrient changes over the season, with the exception of relatively large variability in many of the micronutrients and $\mathrm{Mg}$. We confirmed that leaf $\mathrm{Mn}$ and $\mathrm{Al}$ are good indicators of a reduction in soil $\mathrm{pH}$. Leaf $\mathrm{Al}$ in blueberry was 


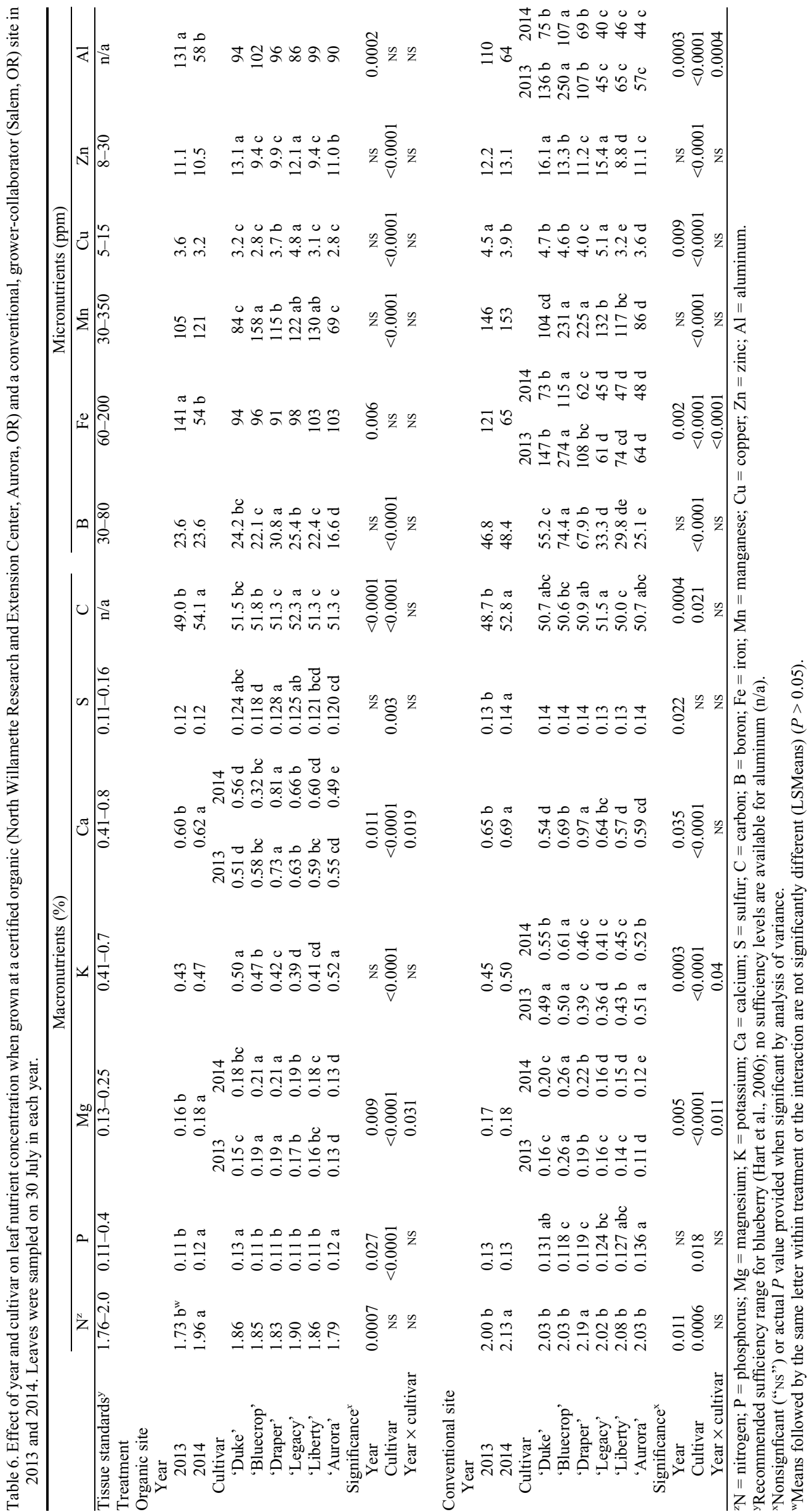



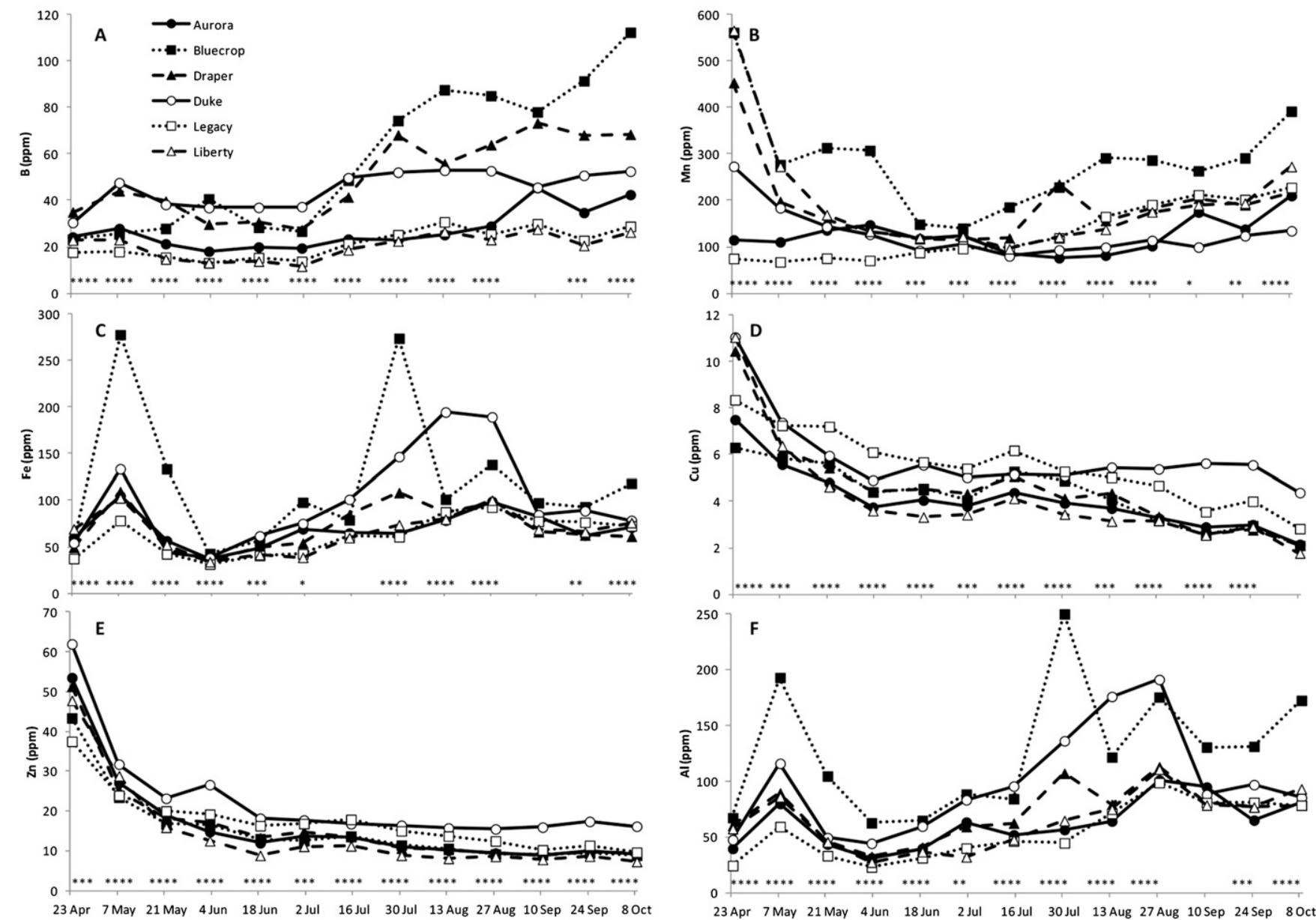

Fig. 6. Effect of cultivar on the concentration of micronutrients in leaves when sampled over the growing season in 2013 at the conventionally managed growercollaborator site, Salem, OR. A = boron; $\mathbf{B}=$ manganese; $\mathbf{C}=$ iron; $\mathbf{D}=$ copper; $\mathbf{E}=$ zinc; $\mathbf{F}=$ aluminum. The main effect of cultivar is significant at $* P \leq 0.05$, $* * P \leq 0.01, * * * P \leq 0.001$, and $* * * * P \leq 0.0001$.
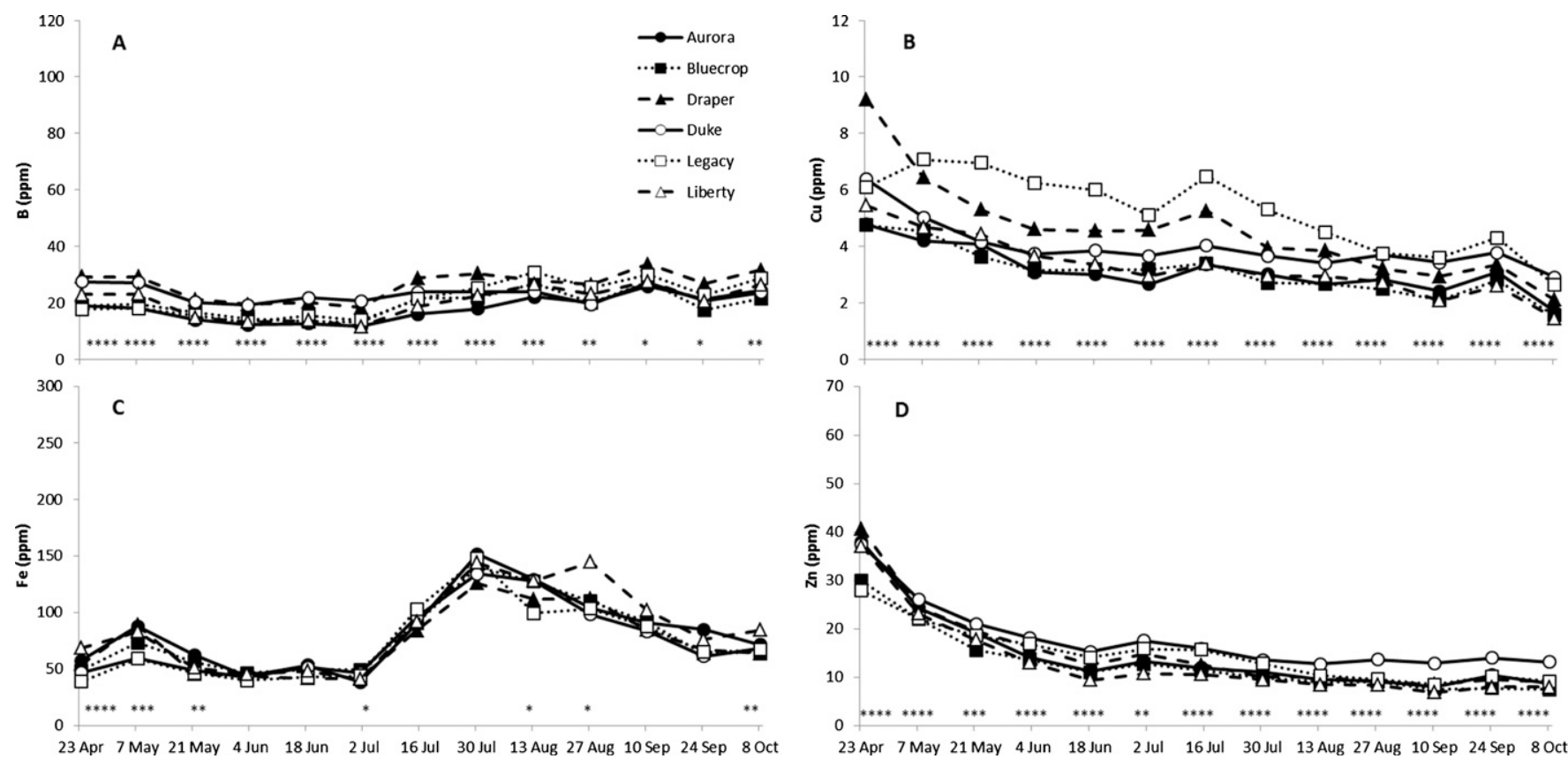

Fig. 7. Effect of cultivar on the concentration of micronutrients in leaves when sampled over the growing season in 2013 at the certified, organic blueberry site, North Willamette Research and Extension Center, Aurora, OR. Averaged over amendment-mulch type. $\mathbf{A}=$ boron; $\mathbf{B}=\operatorname{copper} ; \mathbf{C}=$ iron; $\mathbf{D}=$ zinc. The main effect of cultivar is significant at $* P \leq 0.05, * * P \leq 0.01,{ }^{*} * * P \leq 0.001$, and $* * * * P \leq 0.0001$. 
found to range from 40 to $250 \mathrm{ppm}$ in these cultivars, depending on soil $\mathrm{pH}$.

The pattern in nutrient changes over the season was similar between the organic and conventional sites, but fewer differences in nutrient concentrations were found among cultivars at the organic site. Leaf $\mathrm{N}$ and $\mathrm{K}$ and fruit $\mathrm{N}$ were lower at the organic site but fruit $\mathrm{K}$ was higher than at the conventional site, despite yields being relatively similar. The rate of fertilizer $\mathrm{K}$ applied at the organic site was similar to or greater than at the conventional site, however there was a considerable amount of $\mathrm{K}$ applied in the compost amendment and mulch which increased available soil $\mathrm{K}$, on average. While there was an estimated $25 \mathrm{~kg} / \mathrm{ha} /$ year of $\mathrm{N}$ slowly released by the yard debris compost (Gale et al., 2006; Sullivan et al., 2003), this and any other mineralized $\mathrm{N}$ was likely available later in the season, after leaf and fruit tissue sampling. There was no evidence in plant growth or yield that $\mathrm{N}$ was deficient at the organic site. When $\mathrm{N}$ fertilizer rate was increased at the conventional site in 2014, leaf $\mathrm{N}$ decreased, perhaps a dilution effect, and yield decreased for many cultivars.

Nitrogen and $\mathrm{K}$ were the major nutrients removed in the harvested fruit leading to significant losses of these nutrients for highyielding cultivars. Yield differed as much as 2-fold among the cultivars studied, yet this led to relatively small differences in leaf $\mathrm{N}$ at the recommended sampling time. 'Legacy', the highest yielding cultivar, did tend to have amongst the lowest fruit $\mathrm{N}$ and $\mathrm{K}$ and leaf $\mathrm{K}$ concentrations. While there were differences in leaf $\mathrm{N}$ and $\mathrm{K}$ among the early- to lateseason cultivars studied, they all fell within the current recommended standards when leaves were sampled in late July to midAugust. However, development of cultivarspecific fertilizer programs may improve plant performance and yield over time.

Leaf $\mathrm{P}$ was at the very low end of the current sufficiency range for all cultivars at both sites despite high soil $\mathrm{P}$ and no evidence of $\mathrm{P}$ deficiency. Considering the relatively low tissue $P$ for leaves and fruit, we suggest lowering the leaf sufficiency range for $P$; this would reduce the possibility of growers applying excessive fertilizer $\mathrm{P}$ to try to increase leaf $\mathrm{P}$ to the currently high published sufficiency levels. In addition, leaf $\mathrm{Cu}$ was well below current sufficiency standards for all cultivars and we recommend lowering these standards as the existing levels may have been developed when copper fungicide use was common in blueberry.

\section{Literature Cited}

Amling, H.J. 1958. Influence of nutrient-elemental supply on leaf composition and growth of highbush blueberry (Vaccinium corymbosum L.) with special reference to importance of sampling date on leaf and fruit composition of field-growth blueberries. Michigan State Univ., East Lansing, MI, PhD Diss.

Archbold, D.D., J.G. Strang, and D.M. Hines. 1989. Yield component responses of hull thornless blackberry to nitrogen and mulch. HortScience 24:604-607.
Bailey, J.S., A.F. Spelman, and B. Gersten. 1962. Seasonal changes in the nutrients in the leaves of Rubel blueberry bushes. Proc. Amer. Soc. Hort. Sci. 80:327-330.

Ballinger, W.E. 1966. Seasonal trends in Wolcott blueberry (Vaccinium corymbosum L.) leaf and berry composition. North Carolina Agr. Expt. Sta. Tech. Bul. No. 173.

Ballinger, W.E. and L.J. Kushman. 1966. Factors affecting the mineral-element content of leaves and fruit of Wolcott blueberries. Proc. Amer. Soc. Hort. Sci. 88:325-330.

Ballinger, W.E., L.J. Kushman, and J.F. Brooks. 1963. Influence of crop load and nitrogen applications upon yield and fruit qualities of Wolcott blueberries. Proc. Amer. Soc. Hort. Sci. 82:264-275.

Bañados, M.P., B.C. Strik, D.R. Bryla, and T.L. Righetti. 2012. Response of highbush blueberry to nitrogen fertilizer during field establishment. I. Accumulation and allocation of fertilizer nitrogen and biomass. HortScience 47:648-655.

Chuntanaparb, N. and G. Cummings. 1980. Seasonal trends in concentration of nitrogen, phosphorus potassium, calcium, and magnesium in leaf portions of apple, blueberry, grape, and peach. J. Amer. Soc. Hort. Sci. 105:933-935.

Clark, J.R., J.B. Buckley, III, and E.W. Hellman. 1988. Seasonal variation in elemental concentration of blackberry leaves. HortScience 23:1080 (abstr.).

Clark, J.R., D. Creech, M.E. Austin, M.E.B. Ferree, P. Lyrene, M. Mainland, D. Makus, L. Neuendorfff, K. Patten, and J.M. Spiers. 1994. Foliar elemental analysis of southern highbush, rabbiteye, and highbush blueberries in the Southern United States. HortTechnology 4:351-355.

Clark, J.R., D.B. Marx, and D.G. Dombek. 1989. Seasonal variation in elemental content of 'Bluecrop' blueberry leaves. Arkansas Arg. Expt. Stn. Bull. 920.

DeFrancesco, J., J.W. Pscheidt, and W. Yang. 2014. Blueberry pest management guide for the Willamette Valley. Oregon State Univ. Ext. Ser. Pub., EM 8538.

Eaton, G.W. and C.N. Meehan. 1971. Effect of leaf position and sampling date on leaf nutrient composition of eleven highbush blueberry cultivars. J. Amer. Soc. Hort. Sci. 96:378-380.

Fernandez-Salvador, J.A., B.C. Strik, and D. Bryla. 2015. Response of blackberry cultivars to fertilizer source in an organic fresh market production system. HortTechnology 25:277-292.

Gale, E.S., D.M. Sullivan, D. Hemphill, C.G. Cogger, A.I. Bary, and E.A. Myhre. 2006. Estimating plant-available nitrogen release from manures, composts, and specialty products. J. Environ. Qual. 35:2321-2332.

Gavlak, R.G., D.A. Horneck, and R.O. Miller. 1994. Plant, soil, and water reference methods for the western region. Western Region Ext. Pub. 125 (WREP-125), Univ. Alaska, Fairbanks, AK.

Gerasopoulos and Drogoudi. 2005. Summerpruning and preharvest calcium chloride sprays affect storability and low temperature breakdown incidence in kiwifruit. Postharvest Biol. Technol. 36:303-308.

Harkins, R., B.C. Strik, and D. Bryla. 2014. Weed management practices for organic production of trailing blackberry.II. Accumulation and loss of biomass and nutrients. HortScience 49:35-43.

Hart, J., E. Hanson, and B. Strik. 1992. Nutrient management. In: M.P. Pritts and J.F. Hancock (eds.). Highbush Blueberry Production Guide. NRAES, Ithaca, New York.

Hart, J., B. Strik, L. White, and W. Yang. 2006. Nutrient management for blueberries in Oregon. Ore. State Univ. Ext. Serv. EM 8918. 20 Apr. 2015. <http://ir.library.oregonstate.edu/xmlui/ bitstream/handle/1957/20444/em8918.pdfs.
Hughes, M., M.H. Chaplin, and A.R. Dixon. 1979. Elemental composition of red raspberry leaves as a function of time of season and position on cane. HortScience 14:46-47.

John, M.K., H.A. Daubeny, and H.H. Chuah. 1976. Factors affecting elemental composition of red raspberry leaves. J. Sci. Food Agr. 27:877-882.

Knee, M. and P. Srivastava. 1995. Binding of calcium by cell walls and estimation of calcium in apple fruit tissue with an ion selective electrode. Postharvest Biol. Technol. 5:19-27.

Kowalenko, C.G. 1994. Growing season changes in the concentration and distribution of macroelements in Willamette red raspberry plant parts. Can. J. Plant Sci. 74:833-839.

Krewer, G., B. Cline, and D. Scott NeSmith. 2007. Southeast regional blueberry horticulture and growth regulator guide. Univ. Georgia Coop. Extension. 5 May 2015. <http://www.smallfruits. org/SmallFruitsRegGuide/Guides/2007/3_ 21_07SR_BlueberryHortGuide.pdf>.

Mohadjer, P., B.C. Strik, B.J. Zebarth, and T.L. Righetti. 2001. Nitrogen uptake, partitioning and remobilization in 'Kotata' blackberries in alternate year production. J. Hort. Sci. Biotechnol. 76:700-708.

Naraguma, J. and J.R. Clark. 1998. Effect of nitrogen fertilization on "Arapaho" thornless blackberry. Commun. Soil Sci. Plant Anal. 29:2775-2783.

Nemeth, D.A. 2013. Patterns of carbon storage within a mature northern highbush blueberry production system. Oregon State Univ., Corvallis, OR, PhD Diss. 5 May 2015. <http://ir. library.oregonstate.edu/xmlui/handle/1957/41676>.

Ochmian, I. 2012. The impact of foliar application of calcium fertilizers on the quality of highbush blueberry fruits belonging to the 'Duke' cultivar. Not. Bot. Horti Agrobo. 40:163-169.

Organic Materials Review Institute (OMRI). 2013. Organic Materials Review Institute Home Page. 12 Dec. 2013. <https://www.omri.org/>.

Retamales, J.B. and E.J. Hanson. 1990. Effect of nitrogen fertilizers on leaf and soil nitrogen levels in highbush blueberry. Commun. Soil Sci. Plant Anal. 21:2067-2078.

Singh, R., R.R. Sharma, and S.K. Tyagi. 2006. Preharvest foliar application of calcium and boron influences physiological disorders, fruit yield and quality of strawberry (Fragaria $\times$ ananassa Duch.). Sci. Hort. 112:215-220.

Spiers, J.M. 1982. Seasonal variation in leaf nutrient composition in 'Tifblue' rabbiteye blueberry. J. Amer. Soc. Hort. Sci. 107:255-257.

Spiers, J.M. 1983. Elemental leaf content and deficiency symptoms in rabbiteye blueberries: 1. Nitrogen. J. Plant Nutr. 6:1059-1071.

Strik, B.C. 2015. Seasonal variation in mineral nutrient content of primocane-fruiting blackberry leaves. HortScience 50:540-545.

Strik, C., C. Brun, M. Ahmedullah, A. Antonelli, L. Askham, D. Barney, P. Bristow, G. Fisher, J. Hart, D. Havens, R. Ingham, D. Kaufman, R. Penhallegon, J. Pscheidt, B. Scheer, C. Shanks, and R. William. 1993. Highbush blueberry production. Oregon State. Univ. Ext. Serv. Pub. PNW 215.

Sullivan, D.M., A.I. Bary, T.J. Nartea, E.A. Myrhe, C.G. Cogger, and S.C. Fransen. 2003. Nitrogen availability seven years after a high-rate food waste compost application. Compost Sci. Util. $11: 265-275$.

U.S. Department of the Interior. 2013. U.S. Department of the Interior, Bureau of Reclamation, AgriMet. Boise, ID. 5 Apr. 2015. <http:// www.usbr.gov/pn>.

Wright, C.J. and P.D. Waister. 1980. Seasonal changes in the mineral nutrient content of the raspberry. Acta Hort. 112:295-304. 